\title{
Vector competence is strongly affected by a small deletion or point mutations in bluetongue virus
}

\author{
René G. P. van Gennip ${ }^{1}$, Barbara S. Drolet ${ }^{2}$, Paula Rozo Lopez ${ }^{2,3}$, Ashley J. C. Roost ${ }^{1}$, Jan Boonstra ${ }^{1}$
} and Piet A. van Rijn ${ }^{1,4^{*}}$

\begin{abstract}
Background: Transmission of vector-borne virus by insects is a complex mechanism consisting of many different processes; viremia in the host, uptake, infection and dissemination in the vector, and delivery of virus during bloodfeeding leading to infection of the susceptible host. Bluetongue virus (BTV) is the prototype vector-borne orbivirus (family Reoviridae). BTV serotypes 1-24 (typical BTVs) are transmitted by competent biting Culicoides midges and replicate in mammalian (BSR) and midge (KC) cells. Previously, we showed that genome segment 10 (S10) encoding NS3/NS3a protein is required for virus propagation in midges. BTV serotypes 25-27 (atypical BTVs) do not replicate in KC cells. Several distinct BTV26 genome segments cause this so-called 'differential virus replication' in vitro.
\end{abstract}

Methods: Virus strains were generated using reverse genetics and their growth was examined in vitro. The midge feeding model has been developed to study infection, replication and disseminations of virus in vivo. A laboratory colony of C. sonorensis, a known competent BTV vector, was fed or injected with BTV variants and propagation in the midge was examined using PCR testing. Crossing of the midgut infection barrier was examined by separate testing of midge heads and bodies.

Results: A $100 \mathrm{nl}$ blood meal containing $\pm 10^{5.3} \mathrm{TCID}_{50} / \mathrm{ml}$ of BTV1 1 which corresponds to $\pm 20 \mathrm{TCID}_{50}$ infected $50 \%$ of fully engorged midges, and is named one Midge Alimentary Infective Dose (MAID $\left.{ }_{50}\right)$. BTV11 with a small in-frame deletion in $\mathrm{S} 10$ infected blood-fed midge midguts but virus release from the midgut into the haemolymph was blocked. BTV11 with S1 [VP1] of BTV26 could be adapted to virus growth in KC cells, and contained mutations subdivided into 'corrections' of the chimeric genome constellation and mutations associated with adaptation to KC cells. In particular one amino acid mutation in outer shell protein VP2 overcomes differential virus replication in vitro and in vivo.

Conclusion: Small changes in NS3/NS3a or in the outer shell protein VP2 strongly affect virus propagation in midges and thus vector competence. Therefore, spread of disease by competent Culicoides midges can strongly differ for very closely related viruses.

Keywords: Bluetongue virus, Culicoides, Arbovirus, Vector competence, Virus propagation, Feeding model, Midge

\section{Background}

Arthropod-borne viruses have a significant social and economic impact on both human and animal health. The majority of emerging and re-emerging infectious

\footnotetext{
*Correspondence: piet.vanrijn@wur.nl

${ }^{1}$ Department of Virology, Wageningen Bioveterinary Research, Lelystad, The Netherlands

Full list of author information is available at the end of the article
}

diseases are vector-borne and/or zoonotic [1,2]. Vector competence has been defined as the capacity of insects to transmit virus, and plays a key role in spread of vectorborne diseases. Competence of insect vectors has been determined by factors related to the insect species and environmental conditions but also involves specific interactions between host, vector and pathogen. Regarding virus-vector interactions, several processes can be recognized; uptake of virus by blood-feeding, replication in 
the insect vector, dissemination to salivary glands, virus release in saliva and delivery by blood-feeding to the susceptible host, and finally, viremia in the host for subsequent uptake by blood-feeding midges.

Bluetongue (BT) is an insect-borne disease of ruminants which is spread by a limited number of species of biting Culicoides midges (Diptera: Ceratopogonidae). Historically, BT is caused by 24 serotypes of bluetongue virus (BTV) (genus Orbivirus, family Reoviridae) [3], and its worldwide spread is limited to local competent Culicoides vectors. The most relevant Culicoides species regarding spread of disease are C. imicola in Africa/western Asia, C. obsoletus, C. imicola, C. dewulfi and C. pulicaris in Europe, C. sonorensis in North America/Canada, C. insignis in South America, and C. brevitarsis in eastern Asia and Australia. Other transmission mechanisms such as vertical transmission in animals seems to be more common for cell-culture adapted BTV, like live attenuated vaccine viruses, than for wild type (wt) BTV1-24 [4, 5]. In addition, animal to animal direct contact transmission leading to viremia has been reported in the field as well as in animal trials [6-8].

Feeding of competent $C$. sonorensis midges with blood contaminated with wild type BTV11 (wtBTV11) has resulted in infection, replication and dissemination of wtBTV11 in fully engorged midges [9]. BTV without NS3/NS3a expression is named BT Disabled Infectious Single Animal (DISA) vaccine, since bite transmission by midges is blocked [10]. NS3/NS3a of BTV is not essential for virus replication in a mammalian cell line, but culturing in Culicoides cells is abolished by lack of virus release [11], here named 'differential virus replication' in vitro. Furthermore, NS3/NS3a encoded by genome segment $\mathrm{S} 10$ is the prototype virus protein involved in differential virus replication in vivo, since virus propagation after intrathoracic inoculation of midges is abolished [9].

In the last decade, new BTV serotypes (25-27) have been found in goats showing unique characteristics [12-14] and are named atypical BTVs [15]. BTV25 could not be isolated despite extensive efforts, but has been successfully passaged in goats using BTV25 containing blood for infection [16]. BTV26 and 27 have been isolated in mammalian cells but culturing in Culicoides (KC) cells has failed. Animal trials in vector-free conditions showed virus spread by direct contact transmission $[17,18]$, but vector-borne transmission of atypical BTVs in the field cannot be ruled out. It has been previously shown that VP2, 5, 7 and NS3/NS3a of atypical BTV25 are functional in the backbone of typical BTV [19]. Similarly, all genome segments S1-10 of BTV26 are functional in BTV1 [RSArrrr/01], although BTV1 with S1[VP1], S3[VP3], or the combination of S2[VP2], S6[VP5], and S7[VP7] of BTV26 did not replicate in KC cells [20].
Since some BTV26 genome segments cause 'differential virus replication in vitro', virus propagation in competent midges of these BTV1/BTV26 reassortants is likely abolished.

To further investigate differential virus replication in vitro and in vivo, a small in-frame deletion in NS3/NS3a and typical BTV containing S1[VP1] of atypical BTV26 were evaluated for their ability to replicate in mammalian and Culicoides cell lines and in C. sonorensis midges. Effects of viral genetics on vector competence is discussed.

\section{Methods}

\section{Cell lines and viruses}

BSR cells (a clone of baby hamster kidney cells) [21] were cultured in Dulbecco's modified Eagle's medium (DMEM; Invitrogen, Carlsbad, CA, USA) containing 5\% foetal bovine serum (FBS), and antibiotics (100 IU/ml Penicillin, $100 \mu \mathrm{g} / \mathrm{ml}$ Streptomycin and $2.5 \mu \mathrm{g} / \mathrm{ml}$ Amphotericin B) at $37^{\circ} \mathrm{C}$. Culicoides $(\mathrm{KC})$ cells were grown in modified Schneider's Drosophila medium with $15 \%$ heat inactivated $\mathrm{FBS}, 100 \mathrm{IU} / \mathrm{ml}$ penicillin and $100 \mu \mathrm{g} / \mathrm{ml}$ streptomycin at $28^{\circ} \mathrm{C}$ [22].

BTV26 [reference collection sample BTV26KUW2010/12 BHK2 ex animal B3, [23] (http://www.reovi ridae.org/dsrna_virus_proteins/) was purchased from The Pirbright Institute, UK]. A virus stock was obtained by one passage on BSR cells at Wageningen Bioveterinary Research (WBVR) and designated BTV26. BTV11 was isolated from the spleen of a white-tailed deer from Texas in 2011, passaged once in embryonated chicken eggs, and four times in BHK21 cells before use in midge feeding/injecting. A virus stock for in vitro experiments was obtained by one passage on BSR cells at WBVR, and designated wtBTV11. All other viruses in this study were generated by reverse genetics [24]. These 'synthetic' viruses are based on rgBTV1 $[25,26]$ and rgBTV11 (this study). After virus rescue, virus stocks were obtained by infection of fresh BSR cell monolayers with a multiplicity of infection (MOI) of 0.1 , and stored at $4{ }^{\circ} \mathrm{C}$.

\section{CDNAs of BTV genome segments}

Complete genome segments 1 to 10 (S1-S10) of virus backbones BTV1 (accession numbers FJ969719-28) and BTV11 (GenBank: KM580433-442; [27]) were synthesized as cDNAs by Genscript corporation (Piscataway NJ, USA) in appropriate plasmids under control of the T7 promoter and restriction enzyme sites suitable for runoff RNA transcription [25]. In addition, cDNA of S10 of BTV11 (GenBank: KM580440) was synthesized with an in-frame deletion of 72 amino acid (aa) codons, nucleotide positions 124-339, which encompasses Late Domain motif PPXY/PTAP [28] and corresponds to aa positions 
35-106 (S10 $\left.{ }^{\mathrm{del}}\right)$. Similarly, three chimeric cDNAs encoding $\mathrm{S} 1$ [VP1; the RNA-dependent RNA polymerase (RdRp)], containing the same BTV11 as above $\left(\mathrm{S}^{11}\right)$ and BTV26 (GenBank: JN255156.1; [23]) $\left(\mathrm{S1}^{26}\right)$ sequences were designed and purchased. Each chimeric S1 contained one of three defined domains of the RdRp of BTV26 $\left(\mathrm{S}^{11 / 26}\right)$ [29] and untranslated regions of BTV11. Defined VP1 domains correspond to: (i) the N-terminal domain (NTD), nucleotide positions 12-1774 (BTV11chim26S1_NTD); (ii) the polymerase domain (PD), nucleotide positions 1775-2668 (BTV11chim26S1_ $\mathrm{PD}$ ); and (iii) the C-terminal domain (CTD), nucleotide positions 2669-3937 (BTV11chim26S1_CTD). Capped RNA run-off transcripts were synthesized and stored as previously described [25].

\section{Rescue of BTV variants using reverse genetics}

Reverse genetics for BTV as used in this study has been described [24]. Briefly, BSR cell monolayers were transfected with plasmids expressing optimized genes of VP1, 3, 4, 6, and NS1 and 2 followed by transfection with 10 capped run-off RNA transcripts in equimolar amounts after $24 \mathrm{~h}$. At $4 \mathrm{~h}$ post-RNA transfection, transfection mix was replaced by culture medium, and virus was harvested as described [11]. Modified or exchanged genome segments were confirmed by partial sequencing according to standard procedures.

\section{Adaptation to KC cells}

To increase virus replication in KC cells, rescued BTV on BSR cells were adapted to KC cells by infecting $2 \times$ $10^{5} \mathrm{KC}$ cells per $2 \mathrm{~cm}^{2}$ well with $0.1 \mathrm{ml}$ virus stock. Six days post-infection the supernatant was removed and replaced with $0.2 \mathrm{ml}$ Schneider's complete medium. Cells were scraped from the bottom and resuspended in $25 \mathrm{~cm}^{2}$ flasks with $5 \mathrm{ml}$ Schneider's complete medium. After 7 days, supernatants were harvested and stored at $4{ }^{\circ} \mathrm{C}$. Cells were scraped from the bottom in $1 \mathrm{ml} \mathrm{Sch}-$ neider's complete medium and split 1:10 in $5 \mathrm{ml} \mathrm{Schnei-}$ der's complete medium and grown again for 7 days. The procedure was repeated to generate $\mathrm{p} 2 \mathrm{r}$ and $\mathrm{p} 3 \mathrm{r}$. The harvested BTV11 $\left(\mathrm{S}^{26}\right)$ of $\mathrm{p} 3 \mathrm{r}$ was designated $\mathrm{BTV} 11\left(\mathrm{~S}^{26}\right)$ $\mathrm{kc}(\mathrm{r})$ and was used to infect fresh KC cell monolayers in $25 \mathrm{~cm}^{2}$ flasks at low MOI of 0.1. Supernatants were harvested at 7 days post-infection (dpi) $(3 p r+p 1)$. Virus passages were repeated, resulting in $\mathrm{p} 3 \mathrm{r}+3 \mathrm{p}$, here designated BTV11 $\left(\mathrm{S}^{26}\right) \mathrm{kc}$. Passages of $\mathrm{KC}$ cells infected with synthetically derived BTV11 (rgBTV11) and BTV11 variants with chimeric VP1 proteins were not needed to harvest virus. Even more, passage of these viruses on $\mathrm{KC}$ cell monolayers was successful, whereas infection and subsequent adaptation of BTV26 on KC cell monolayers failed.

\section{Immunoperoxidase monolayer assay (IPMA)}

BTV infection of cell monolayers was confirmed by immunoperoxidase monolayer assay (IPMA) according to standard procedures as previously described for BTV [25]. Briefly, fixed infected monolayers were incubated with monoclonal antibody ATCC-CRL1875 against BTV VP7 followed by conjugated rabbit $\alpha$-mouse serum (DAKO, Leuven, Belgium).

\section{Full genome sequencing of BTV11 variants}

RNA from different virus stocks was isolated through High Pure viral RNA kit (Roche, Basel, Switzerland) and all ten genome segments were amplified with the OneStep RTPCR kit (Qiagen, Hilden, Germany) using virus specific primers as described [25]. Amplified cDNAs were sequenced using the BigDye ${ }^{\circledR}$ Terminator v3.1 Cycle Sequencing Kit in a ABI PRISM ${ }^{\circledR} 3130$ Genetic Analyzer (both supplied by Applied Biosystems, Foster City, IA, USA). Sequencing of ultimate $5^{\prime}$ - and $3^{\prime}$-ends of genome segments was performed by a modified method. Therefore, infected BSR monolayers were harvested at total cytopathogenic effect (CPE). A volume of $0.1 \mathrm{ml}$ Trizol $/ \mathrm{cm}^{2}$ monolayer was added and cells were incubated for $5 \mathrm{~min}$ at room temperature. After harvesting disrupted cells, $0.2 \mathrm{ml}$ chloroform $/ \mathrm{ml}$ Trizol was added and the mixture was centrifuged for $10 \mathrm{~min}$ at $6200 \times \mathrm{g}$. The water phase was collected, and $0.8 \mathrm{ml}$ isopropanol/ $\mathrm{ml}$ was added. Precipitated RNA was centrifuged for 30 min at $4{ }^{\circ} \mathrm{C}$ and $13,000 \times \mathrm{rpm}$. The pellet was washed with $70 \%$ ethanol and dissolved in $100 \mu \mathrm{l}$ RNase-free water. Fifty $\mu \mathrm{l}$ of $7 \mathrm{M} \mathrm{LiCl}$ was added, followed by incubation for $30 \mathrm{~min}$ at $-20{ }^{\circ} \mathrm{C}$ to precipitate ssRNA. After centrifugation for $15 \mathrm{~min}$ at $4{ }^{\circ} \mathrm{C}$ and $13,000 \times \mathrm{rpm}$, dsRNA was purified from the supernatant using the RNA clean and concentrator ${ }^{\mathrm{tm}}-5$ kit (Zymo research, Irvine, CA, USA) according to manufacturer's protocol. Two-hundred ng anchor oligo PC3-T7loop [30] was ligated to 100 ng dsRNA with T4 RNA ligase (Bioke, Leiden, the Netherlands) according to manufacturer's conditions for $2 \mathrm{~h}$ at $37^{\circ} \mathrm{C}$. RNA was purified using RNA clean and concentrator $^{\mathrm{tm}}-5$ kit (Zymo research). Ligated RNA was reverse transcribed using random primers with Superscript III (Invitrogen, Carlsbad, CA, USA) according manufacturer's conditions, and cDNA was amplified with PC2 [30] and a specific internal primer for each end of each genome segment with TakaraZ Extaq (Takara Bio, Göteborg, Sweden).

\section{Growth kinetics and virus release}

To determine virus replication, monolayers of $2 \times 10^{5}$ BSR cells or $2 \times 10^{6} \mathrm{KC}$ cells in $2 \mathrm{~cm}^{2}$ wells were infected in duplicate at a multiplicity of infection (MOI) of 0.1. To study virus release, monolayers of $5 \times 10^{5}$ BSR cells 
or $5 \times 10^{6} \mathrm{KC}$ cells in $2 \mathrm{~cm}^{2}$ wells were infected with an MOI of 0.01 . After virus attachment for $1.5 \mathrm{~h}$ at $37{ }^{\circ} \mathrm{C}$ to BSR cells, or at $28^{\circ} \mathrm{C}$ to $\mathrm{KC}$ cells, media was removed and monolayers were washed twice with phosphate-buffered saline (PBS), and $1 \mathrm{ml}$ DMEM complete medium (BSR cells) or $1 \mathrm{ml} \mathrm{Schneider's} \mathrm{complete} \mathrm{medium} \mathrm{(KC} \mathrm{cells)}$ was added. This time point was set as $0 \mathrm{~h}$ post-infection (hpi). Infected monolayers were incubated at appropriate temperature for indicated hpi, and were subsequently stored at $-80{ }^{\circ} \mathrm{C}$. In case of virus release assays, cells and culture medium were separately harvested. Fractions containing cells were lysed by freeze-thawing at $-80{ }^{\circ} \mathrm{C}$, centrifuged, and supernatant was stored. Virus titers in each sample were determined by infection of BSR cells with tenfold dilutions. After incubation for $72 \mathrm{~h}$, wells were monitored for CPE and immunostaining by IPMA. Virus titers were expressed as tissue culture infective doses $\left(\mathrm{TCID}_{50} / \mathrm{ml}\right.$ or $\left.\log _{10} \mathrm{TCID}_{50} / \mathrm{ml}\right)$. Growth kinetics and virus release assays were determined at least twice and virus titrations were independently repeated.

\section{Feeding and inoculation of midges}

Feeding of midges were performed as previously described [9]. For feeding, colonized 3-4 day-old female C. sonorensis midges from the Arthropod-Borne Animal Diseases Research Unit, Manhattan, KS, USA [31] were offered a blood meal, consisting of $1: 1(\mathrm{v} / \mathrm{v})$ defibrinated sheep blood and indicated virus titer in an artificial feeder using a parafilm membrane [32]. Midges were allowed to feed for $2 \mathrm{~h}$. Then, they were anesthetized for 10-15 s with $\mathrm{CO}_{2}$ and sorted as to blood-feeding status on a $\mathrm{CO}_{2}$ fly pad (Diamed Lab Supplies, Inc., Mississauga, Ontario, CA). Twenty-five engorged females were immediately placed in $100 \mu \mathrm{l}$ RNAlater (Qiagen, Germantown, MD, USA) and stored at $4{ }^{\circ} \mathrm{C}$. This time point was set as 0 days post-feeding $(0 \mathrm{dpf})$. Further, engorged females were put in cardboard cages with cotton plugged vials containing $10 \%$ sucrose and held at $26^{\circ} \mathrm{C}$ for 10 days $(10 \mathrm{dpf})$. At $10 \mathrm{dpi}, 25$ midges were decapitated using ultra-fine tweezers (EMS Hatfield, PA, USA) and a dissecting microscope (SMZ 1500; Nikon Instruments, Melville, NY, USA). Heads and bodies were separately placed in $100 \mu \mathrm{l}$ RNAlater and stored at $4{ }^{\circ} \mathrm{C}$.

For inoculation, colonized 3-4 day-old female $C$. sonorensis midges were intrathoracically microinjected (Nanoject II, Drummond Scientific, Broomall, PA, USA) with $46 \mathrm{nl}$ cell culture media containing indicated virus titer [9]. Twenty-five injected midges were placed in 100 $\mu \mathrm{l}$ RNAlater $1-4 \mathrm{~h}$ post-injection, and stored at $4{ }^{\circ} \mathrm{C}$. This time point was set as 0 days post-inoculation $(0 \mathrm{dpi})$. Any variation in time that occurred after injection was due to the time-intensive nature of microinjection of midges. Similar to fed midges, inoculated midges were held at $26^{\circ} \mathrm{C}$ for 10 days ( $10 \mathrm{dpi}$ ), and groups of 25 midges were processed as described above.

\section{RNA isolation and PCR testing}

To study the presence of BTV-RNA, bodies and heads were PCR tested as described [9]. Briefly, $400 \mu \mathrm{PBS}$ and one $5 \mathrm{~mm}$ stainless steel ball (Qiagen) were added to individual bodies and heads in RNAlater in micronic tubes. Tubes were shaken for $3 \mathrm{~min}$ at $50 \mathrm{~Hz}$ in a tissue lyser (85600, Qiagen). After centrifugation, $200 \mu \mathrm{l}$ of supernatant was used for RNA isolation. BTV-RNA was detected by the panBTV Seg-10 PCR test or the real time RT-PCR test for Seg-1 [33] adapted to the all-in-one method [33, $34]$. Crossing point $(\mathrm{Cq})$ values were calculated, and negative results were arbitrarily set as 45 . Due to the maximum of 45 cycles, the highest Cq value that could still be calculated was 40 .

\section{Results}

\section{Rescue of BTV11}

To study the role of viral proteins in BTV replication in midges, we first regenerated BTV11 by reverse genetics (rgBTV11). As expected, rgBTV11 efficiently replicated in vitro in BSR and KC cells (Fig. 1). We also showed that rgBTV11 replicates in competent midges like wild type BTV11 (wtBTV11) as previously shown [9]. Thus, rgBTV11 is indistinguishable from wtBTV11 and an attractive virus backbone to study the role of viral proteins in differential virus replication in vitro and in vivo.

\section{BTV11 with an in-frame deletion in NS3 is not released from $K C$ cells}

BTV11 was rescued with Seg-10 encoding NS3/NS3a lacking 72 aa codons from position 36 to 107 of NS3 $\left(\mathrm{S} 10^{\mathrm{del}}\right)$ encompassing Late Domain. BTV11(S10 del $)$ developed small plaques (CPE) on BSR monolayers similar to previous NS3 knockout mutants of BTV1, BTV6/ net08, and BTV8/net06 [10, 11, 35]. Growth and release of BTV11(S10 $\left.{ }^{\mathrm{del}}\right)$ was studied in BSR and KC cell cultures (Fig. 1). BTV11(S10 $\left.{ }^{\text {del }}\right)$ replicated slower in BSR cells than rgBTV11, although both reached a virus titer in the cellassociated fraction and culture medium of \pm 7 and \pm 5.5 $\log _{10} \mathrm{TCID}_{50} / \mathrm{ml}$, respectively, at $96 \mathrm{hpi}$.

In $\mathrm{KC}$ cells, BTV11(S10 $\left.{ }^{\text {del }}\right)$ marginally replicated and stabilized at $\pm 4 \log _{10} \mathrm{TCID}_{50} / \mathrm{ml}$. In contrast, rgBTV11 steadily grew to $\pm 7 \log _{10} \mathrm{TCID}_{50} / \mathrm{ml}$ at $96 \mathrm{hpi}$ (Fig. 1). Clearly, BTV11(S10 $\left.{ }^{\text {del }}\right)$ was not released into culture medium of $\mathrm{KC}$ cells, whereas rgBTV11 was readily 


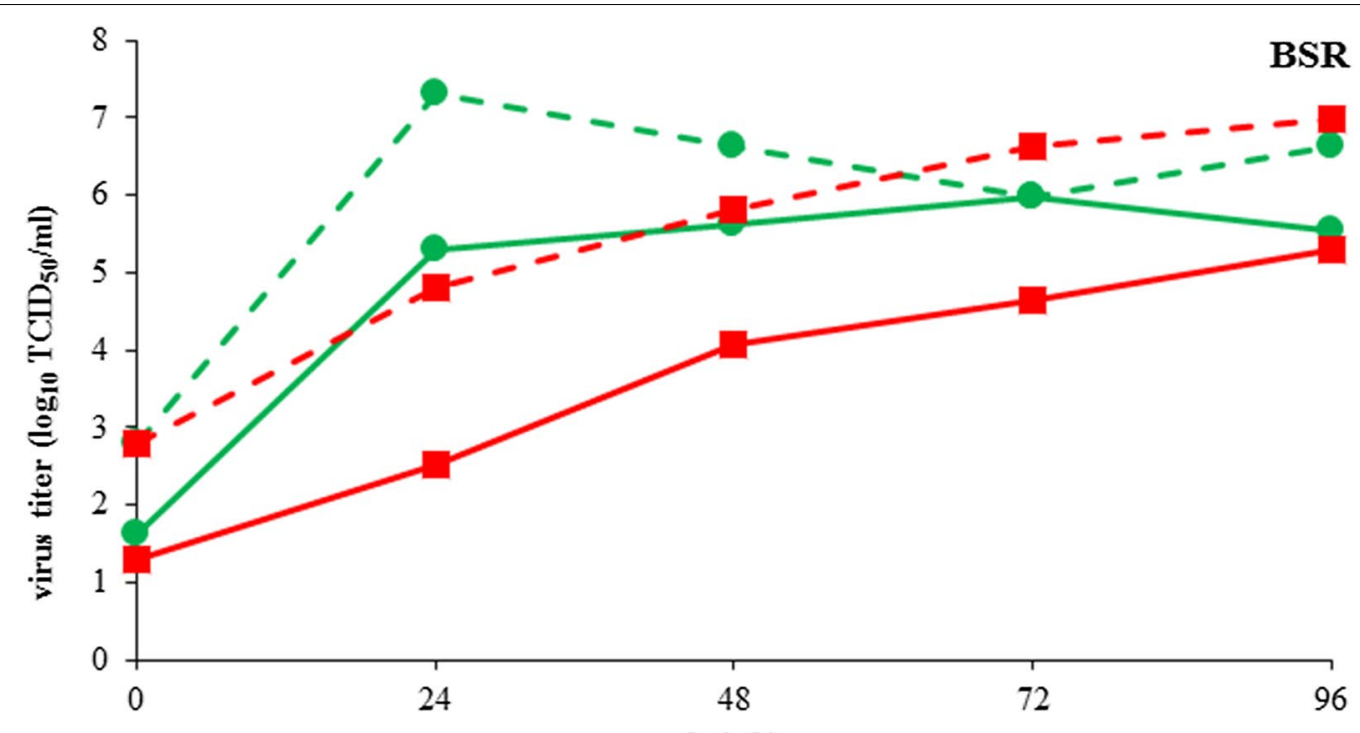

hpi (h)

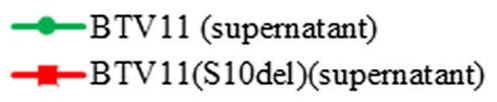

$-\bullet$ BTV11 (cell associated)
- - BTV11(S10del)(cell associated)

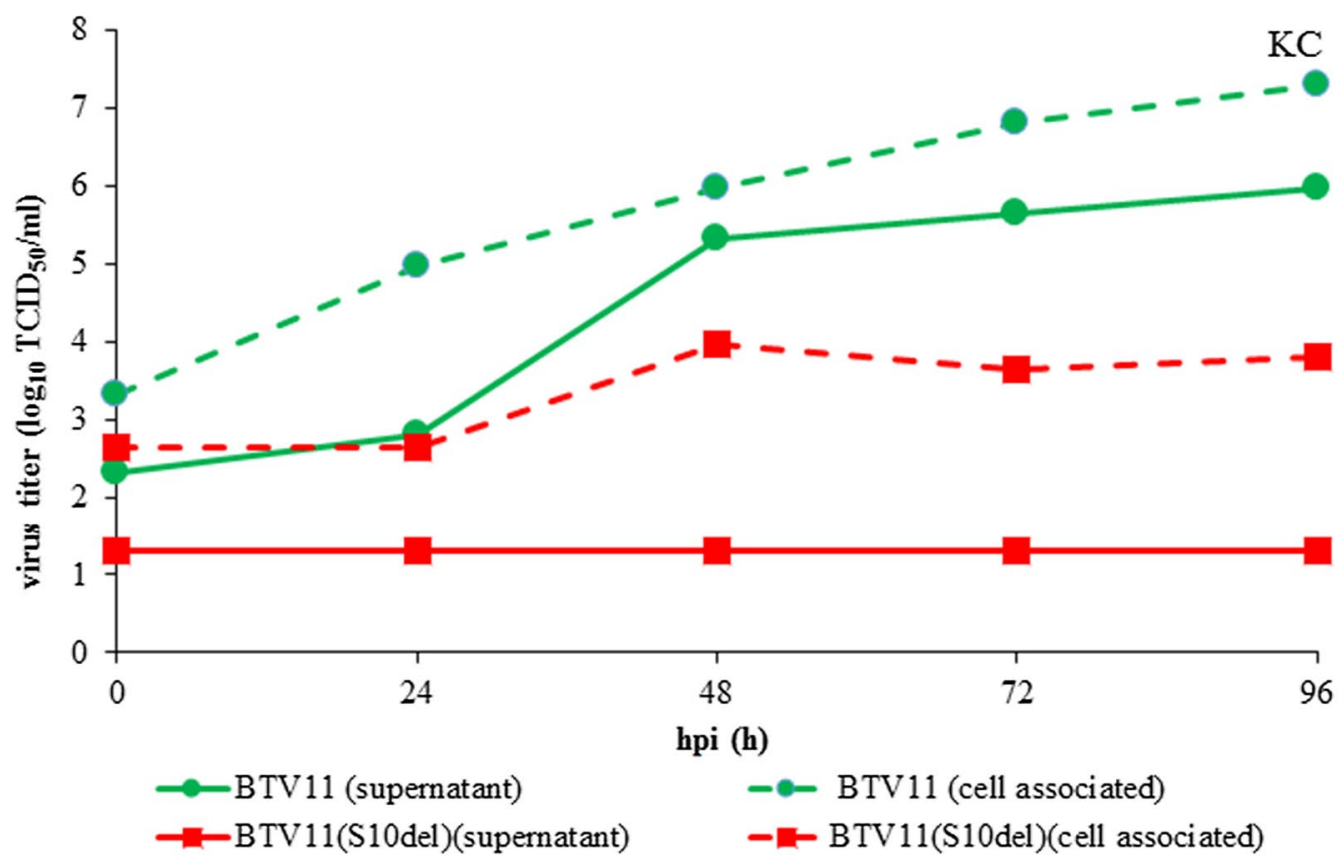

Fig. 1 Virus release from BSR and KC cells. Cell-associated virus (dashed lines) and released virus (lines) were determined for BTV1 1(S10 del)(squares) and rgBTV11 (circles) in infected monolayers of BSR and KC cells at indicated hours post-infection (hpi). Virus titers are expressed aslog ${ }_{10} \mathrm{TCID}_{50}$ per $\mathrm{ml}$. Representative results are shown

released from $\mathrm{KC}$ cells to $5.3 \log _{10} \mathrm{TCID}_{50} / \mathrm{ml}$ at $48 \mathrm{hpi}$, and further increased to $7.3 \log _{10} \mathrm{TCID}_{50} / \mathrm{ml}$ at $96 \mathrm{hpi}$. This suggests that the Late Domain of NS3/NS3a protein is essential for virus propagation in $\mathrm{KC}$ cells, but not essential for virus replication in BSR cells, which is here named 'differential virus replication' in vitro.
Domains in VP1 of BTV26 are not responsible for differential virus replication in vitro

BTV1-based reassortants with genome segment 1 of BTV26 $\left(\mathrm{S}^{26}\right)$ expressing VP1 (RdRp) did not replicate in $K C$ cells [20]. Here, we used this finding to map domains in RdRp involved in differential virus replication in vitro. 
BTV 11/26 chimeric S1 segments encoding one out of three defined $\mathrm{RdRp}$ domains of $\mathrm{VP} 1^{26}$ were incorporated in BTV11 using reverse genetics. All three BTV11 mutants expressing these chimeric $\mathrm{VP} 1^{11 / 26}$ proteins with domain NTD, PD or CTD of VP1 ${ }^{26}$ were rescued, and could be serially passed in both BSR cells and KC cells. Apparently, none of the RdRp domains of $\mathrm{VP}{ }^{26}$ is involved in differential virus replication. In conclusion, with this approach, we were unable to identify domains in $\mathrm{VP} 1^{26}$ involved in differential virus replication. We suggested that several domains of $\mathrm{VP}^{26}$ contribute to differential virus replication or that entire $\mathrm{VP}^{26}$ in the BTV11 backbone is functional in virus replication in $\mathrm{KC}$ cells.

\section{BTV11 expressing VP1 of BTV26 replicates in KC cells after adaptation}

As a next step, BTV11 $\left(\mathrm{S}^{26}\right)$ expressing VP1 of BTV26 was rescued. Rescue of $\mathrm{BTV} 11\left(\mathrm{S1}^{26}\right)$ was less efficient than its ancestor rgBTV11 or BTV11 expressing VP1 $1^{11 / 26}$ protein, as described above. Transfected cells were passed once to obtain cytopathogenic effect (CPE).
Harvested BTV11 $\left(\mathrm{S}^{26}\right)$ was passed once on fresh BSR cells and virus stocks were used for subsequent experiments. Initially, BTV11 $\left(\mathrm{S1}^{26}\right)$ was not detected in culture medium of infected $\mathrm{KC}$ cell monolayers but some $\mathrm{KC}$ cells were immunostained (Fig. 2c), suggesting very weak protein expression and possibly virus replication. Duplicate infected $\mathrm{KC}$ cell monolayers were blindly passaged three times to 'rescue' virus. Virus was harvested from the 3rd passage (p3r) and was named BTV11(S1) ${ }^{26} \mathrm{kc}(\mathrm{r})$. This virus was subsequently passed three times by infection of fresh $\mathrm{KC}$ cell monolayers $(\mathrm{p} 3 \mathrm{r}+\mathrm{p} 3)$, and was named BTV11 $\left(\mathrm{S}^{26}{ }^{26} \mathrm{kc}\right.$. In parallel, BTV11(S1 $\left.{ }^{26}\right)$ was passaged three times on BSR cells by infection of fresh BSR cell monolayers, and was named BTV11 $\left(\mathrm{S}^{26}\right) \mathrm{bsr}$.

Virus growth of BTV11(S1) ${ }^{26} \mathrm{kc}(\mathrm{r}), \mathrm{BTV} 11\left(\mathrm{~S}^{26}\right) \mathrm{kc}$ and BTV11(S1 $\left.{ }^{26}\right)$ bsr was studied in BSR and KC cells (Fig. 3). $\mathrm{BTV} 11\left(\mathrm{S1}^{26}\right) \mathrm{bsr}$ replicated in BSR cells, whereas replication in KC cells was marginal (Fig. 3). Similar results have been obtained with VP1 ${ }^{26}$ in the BTV serotype 1 backbone [20]. BTV11 $\left(\mathrm{S}^{26}\right) \mathrm{kc}(\mathrm{r})$ and BTV11 $\left(\mathrm{S}^{26}\right) \mathrm{kc}$ replicated similar to BTV11 $\left(\mathrm{S}^{26}\right) \mathrm{bsr}$ in BSR cells up to 48 hpi but reached higher virus titers at $72 \mathrm{hpi}$. In contrast

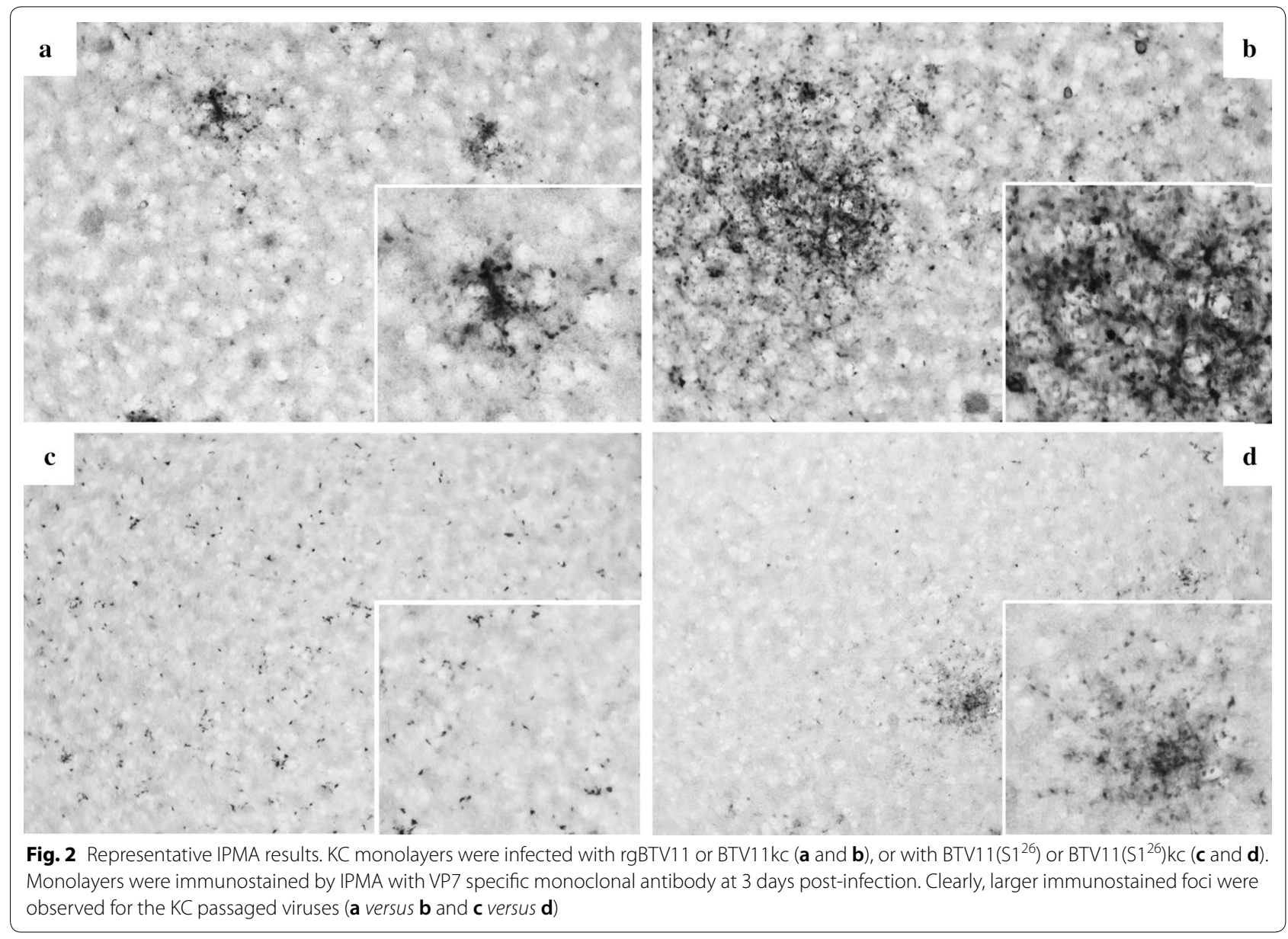


to $\mathrm{BTV} 11\left(\mathrm{S1}^{26}\right) \mathrm{bsr}$, BTV11 $\left(\mathrm{S1}^{26}\right) \mathrm{kc}(\mathrm{r})$ replicated in $\mathrm{KC}$ cells, and was even higher (after three subsequent virus passages) for BTV11 $\left(\mathrm{S}^{26}\right) \mathrm{kc}$. Both $\mathrm{KC}$ variants grew to virus titers of $\pm 7 \log _{10} \mathrm{TCID}_{50} / \mathrm{ml}$ at $144 \mathrm{hpi}$, indicating favouring virus replication in KC cells. Remarkably, $\mathrm{BTV} 11\left(\mathrm{~S}^{26}\right) \mathrm{kc}(\mathrm{r})$ and BTV11 $\left(\mathrm{S1}^{26}\right) \mathrm{kc}$ also reached higher virus titers on $\mathrm{BSR}$ cells than BTV11 $\left(\mathrm{S}^{26}\right)$ bsr. To unravel adaptation mutations in more detail, rgBTV11 was also virus passaged three times on BSR or KC cells resulting in BTV11bsr and BTV11kc, respectively. BTV11(S126) kc and BTV11kc formed larger immunostained foci at 72 hpi than BTV11 $\left(\mathrm{S1}^{26}\right)$ bsr and BTV11bsr, respectively (Fig. 2). These results demonstrate that rgBTV11kc was also adapted to virus growth on $\mathrm{KC}$ cells.

Adapted variants of rgBTV11 and BTV11 $\left(\mathrm{S}^{26}{ }^{26}\right)$ were studied for virus growth on BSR or KC cells (Fig. 4). Both $\mathrm{rgBTV} 11 \mathrm{kc}$ and $\mathrm{BTV} 11\left(\mathrm{~S}^{26}\right) \mathrm{kc}$ replicated to higher virus titers in BSR and $\mathrm{KC}$ cells, although the difference in BSR cells was less obvious than in $\mathrm{KC}$ cells. Further, we conclude that adaptation to KC cells
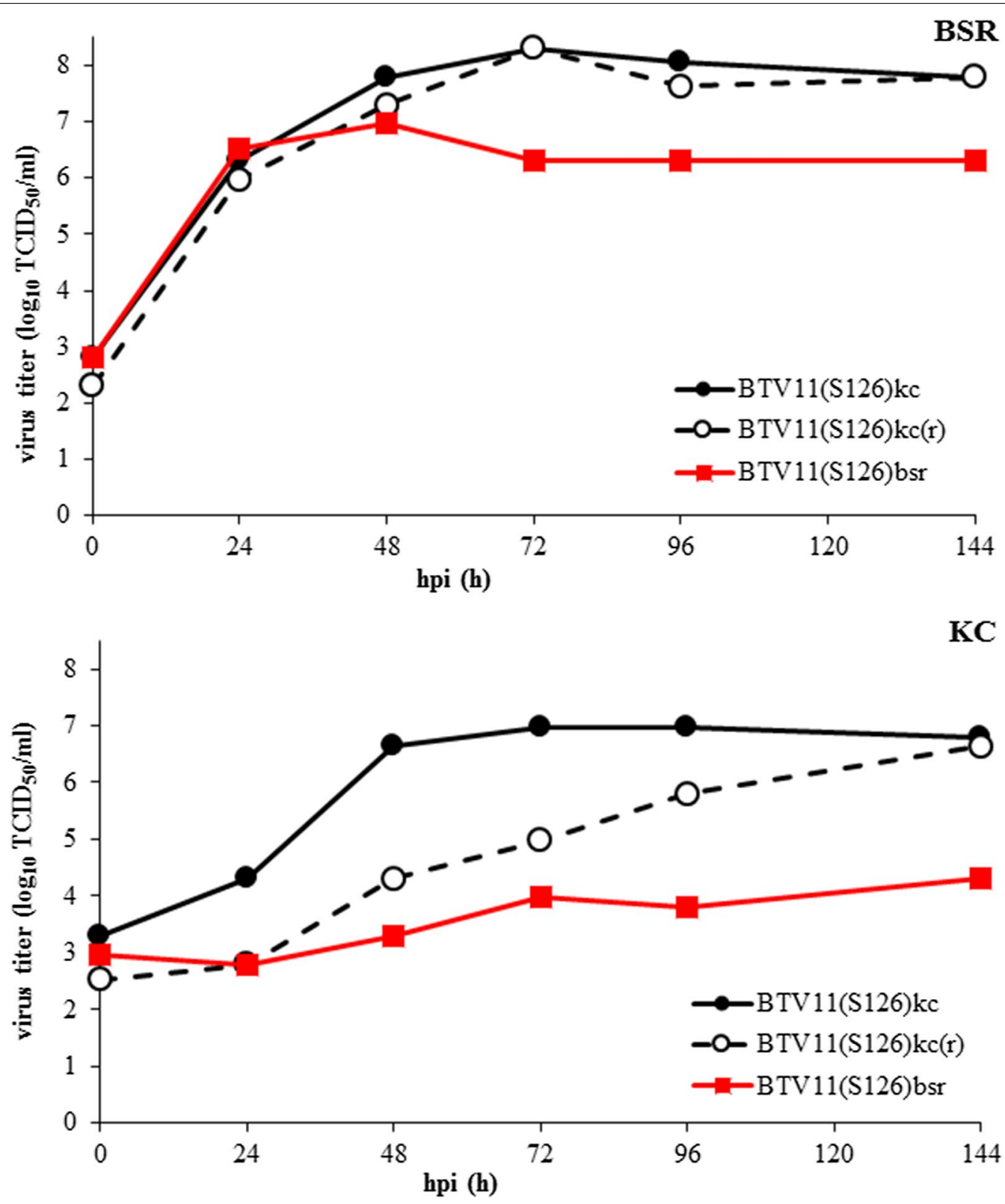

Fig. 3 Virus replication of BSR- and KC-adapted BTV11 expressing VP1 of BTV26. Virus replication was studied for BTV11(S1 $\left.{ }^{26}\right)$ bsr (squares), $\mathrm{BTV} 11\left(\mathrm{~S} 1^{26}\right) \mathrm{kc}(\mathrm{r})$ (open circles), and BTV11(S126)kc (filled circles) in BSR and KC cells. Virus titers were determined at indicated hours post-infection (hpi), and expressed as $\log _{10}$ of $50 \%$ Tissue Culture Infective Dose $\left(T C I D_{50}\right)$ per ml. Representative results are shown 
increased virus replication in both BSR and $\mathrm{KC}$ cells, although this difference is less obvious for rgBTV11 than for BTV11 $\left(\mathrm{S1}^{26}\right)$.

\section{Adaptation mutations are subdivided into chimeric} corrections and virus growth in $\mathrm{KC}$ cells BTV11 $\left(\mathrm{S}^{26}\right) \mathrm{bsr}, \quad \mathrm{BTV} 11\left(\mathrm{~S}^{26}\right) \mathrm{kc}(\mathrm{r})$ and BTV11 $\left(\mathrm{S}^{26}\right)$ kc were completely sequenced and compared to cDNA sequences used to rescue $\mathrm{BTV} 11\left(\mathrm{~S}^{26}\right)$ (Table 1).
BTV11 $\left(\mathrm{S}^{26}\right) \mathrm{bsr}$ contained incomplete nucleotide changes in $\mathrm{S} 1[\mathrm{VP} 1]^{26}, \mathrm{~S} 2[\mathrm{VP} 2]^{11}, \mathrm{~S} 4[\mathrm{VP} 4]^{11}$, and $\mathrm{S} 8[\mathrm{NS} 2]^{11}$. Subsequent virus passages on BSR cells (p6) resulted in three aa mutations; one in S1[VP1] ${ }^{26}$, two in $\mathrm{S} 8\left[_{\mathrm{NS} 2}\right]^{11}$, and one incomplete aa mutation in S4[VP4 $]^{11}$, as well as one incomplete silent mutation in S2[VP2 ${ }^{11}$. These five nucleotide changes were also found after 'rescue' of BTV11 $\left(\mathrm{S1}^{26}\right)$ in KC cells (p3r) but four aa mutations were not completely changed immediately after
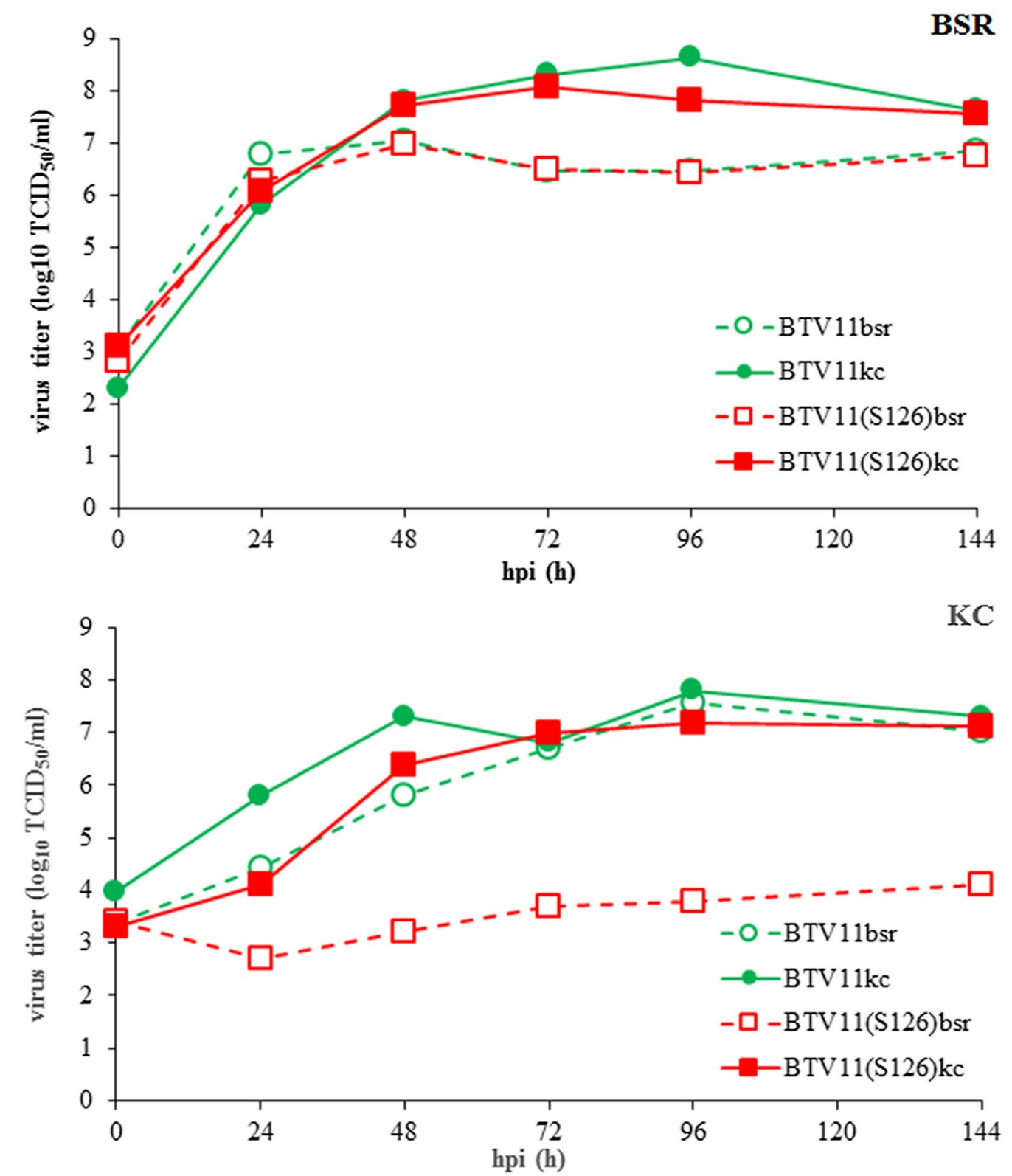

Fig. 4 Comparison of virus replication of BTV11 variants after KC adaptation. Virus replication was studied for rgBTV11 and BTV1 1(S1 $\left.{ }^{26}\right)$ after passages in BSR or KC cells as indicated; BTV1 1 bsr (open circle, dashed line), BTV1 1 kc (filled circle, line), BTV1 (S1 26)bsr (open square, dashed line), and BTV1 $1\left(\mathrm{~S}^{26}\right) \mathrm{kc}$ (filled square, line). Virus titers were determined at indicated hours post-infection (hpi), and expressed as $\log _{10}$ of $50 \%$ Tissue Culture Infective Dose $\left(\mathrm{TCI}_{50}\right)$ per $\mathrm{ml}$. Representative results are shown 
'rescue' in BTV11 $\left(\mathrm{S}^{26}\right) \mathrm{kc}(\mathrm{r})$. Apparently, these aa mutations were rapidly selected in both cell types and are likely associated with chimeric corrections in BTV11 $\left(\mathrm{S}^{26}\right)$. In addition, one incomplete E321G aa mutation in VP2 ${ }^{11}$ was found. After three subsequent virus passages $(\mathrm{p} 3 \mathrm{r}+3 \mathrm{p}), \quad \mathrm{BTV} 11\left(\mathrm{S1}^{26}\right) \mathrm{kc}$ contained three additional incomplete mutations, whereas the incomplete E321G aa change in $\mathrm{VP} 2^{11}$ was complete (Table 1). Silent mutation $\mathrm{A} 53 \mathrm{C}$ in $\mathrm{S} 1[\mathrm{VP} 1]^{26}$ was complete after three subsequent virus passages $(\mathrm{p} 3 \mathrm{r}+\mathrm{p} 6)$, whereas two other incomplete changes remained with mixed nucleotide mutations. The respective regions of BTV11kc and BTV11bsr were also sequenced, but no mutations were found, except for aa mutation E321G in S2[VP2] ${ }^{11}$ in BTV11kc. This indicated that the aa mutation E321G in S2[VP2] ${ }^{11}$ is associated with virus growth in KC cells.

In summary, a total of nine mutations were found in several genome segments after rescue and passages of BTV11 $\left(\mathrm{S}^{26}\right)$ in KC cells. Seven out of nine mutations resulted in aa mutations. Five point mutations (four aa mutations and one silent mutation) are associated with corrections of chimeric interactions, since in BTV11 $\left(\mathrm{S1}^{26}\right)$ bsr contained the same mutation. Four additional point mutations (three aa mutations and one silent mutation) seem to be associated with adaptation to $\mathrm{KC}$ cells, although the selection pressure was not very high since two aa mutations were still incomplete after six virus passages in $\mathrm{KC}$ cells. The most obvious and strongly selected change is aa mutation E321G in VP2 ${ }^{11}$. Even more, rgBTV11 also contained this E321G mutation after virus passages in $\mathrm{KC}$ cells.

\section{Oral infection of midges is dependent on the virus titer in the blood meal}

Virus propagation in vivo was studied in blood-fed midges. For this, individual bodies and heads were tested by PCR directly after feeding $(0 \mathrm{dpf})$ or at $10 \mathrm{dpf}$ to distinguish between infection, replication and dissemination of virus [9]. Firstly, we roughly determined the 50\% infective virus dose by feeding blood containing different virus titers of wtBTV11; L: $10^{5.1} \mathrm{TCID}_{50} / \mathrm{ml}, \mathrm{M}: 10^{6.3}$ $\mathrm{TCID}_{50} / \mathrm{ml}, \mathrm{H}: 10^{8.2} \mathrm{TCID}_{50} / \mathrm{ml}$. Fully engorged midges were selected and processed at $0 \mathrm{dpf}$ to confirm uptake, and at $10 \mathrm{dpf}$ to study virus replication and dissemination (Fig. 5).

Bodies of all groups were PCR-positive at $0 \mathrm{dpf}$, except for one in group $\mathrm{L}$. The difference in virus dose in blood meals was clearly observed. Heads were negative at $0 \mathrm{dpf}$, except for one in groups $\mathrm{L}$ and $\mathrm{M}$ and two in group H. Likely, contamination by decapitation, virus on mouth parts, or incomplete swallowing of the blood meal can occur. At $10 \mathrm{dpf}$, positive results of bodies and

Table 1 Overview of mutations in BTV11(S1 26$)$ variants. BTV11(S126) was passed on BSR or KC cells as described. Rescued virus on KC cells (p3r) and variants after three virus passages (p3) on BSR or KC cells were completely sequenced, whereas virus variants after three additional virus passages (p6 and p3r+p6) were partially sequenced to confirm previously observed mutations. Mutations associated with adaptation to KC cells are in bold

\begin{tabular}{|c|c|c|c|c|c|c|c|}
\hline \multirow{2}{*}{$\begin{array}{l}\text { Genome } \\
\text { segment }\end{array}$} & \multicolumn{3}{|c|}{ BTV11(S126) on BSR cells } & \multicolumn{4}{|l|}{ BTV11(S126) on KC cells } \\
\hline & BTV11(s126)bsr (p3) & p6 & aa mutation & BTV11(S126)kc(r) (p3r) & BTV11(S126)kc (p3r+p3) & $p 3 r+p 6$ & aa mutation \\
\hline S1 & - & nd & - & - & $A 53 C^{a}$ & A53C & silent \\
\hline S1 & A937G ${ }^{a}$ & A937G & D309G & A937G & A937G & A937G & D309G \\
\hline S1 & - & nd & - & - & G3287A (minor) ${ }^{b}$ & $\mathrm{G} 3287 \mathrm{~A}$ (minor) ${ }^{\mathrm{b}}$ & M1092I \\
\hline $\mathrm{S} 2$ & - & nd & - & A981G & A981G & A981G & E321G \\
\hline $\mathrm{S} 2$ & ${\mathrm{C} 2392 \mathrm{~T}^{*} \text { (minor) }}$ & $\left(2392 T(\text { minor })^{b}\right.$ & Silent & C2392T (minor) ${ }^{\mathrm{b}}$ & $\mathrm{C} 2392 \mathrm{~T}$ (minor) ${ }^{\mathrm{b}}$ & C2392T (minor) ${ }^{b}$ & Silent \\
\hline S3 & - & nd & - & - & $\mathrm{C} 2235 \mathrm{~T}(\text { minor })^{\mathrm{b}}$ & $\mathrm{C} 2235 \mathrm{~T}(\text { minor })^{\mathrm{b}}$ & R740C \\
\hline S4 & T1204C ${ }^{a}$ & T1204C & L399S & T1204C & T1204C & T1204C & L399S \\
\hline S5 & - & nd & - & - & - & nd & - \\
\hline S6 & - & nd & - & - & - & nd & - \\
\hline S7 & - & nd & - & - & - & nd & - \\
\hline S8 & C530T ${ }^{\mathrm{a}}$ & C530T & L171F & C530T & C530T & C530T & L171F \\
\hline $\mathrm{S} 8$ & $\mathrm{~A} 681 \mathrm{G}^{\mathrm{a}}$ & A681G & E221G & A681G & A681G & A681G & E221G \\
\hline S9 & - & nd & - & - & - & nd & - \\
\hline $\mathrm{S} 10$ & - & nd & - & - & - & nd & - \\
\hline
\end{tabular}

a $\pm 50 \%$ or mixed nucleotides for each genome segment $\mathrm{S} 1-10$

b $<50 \%$ or minor nucleotide mutations for each genome segment S1-10

Notes: Nucleotide positions are according to positions in the respective genome segments. aa mutations are shown in the right column of each passaged BTV11 variant. Note: mutation A981G in S2 [VP2] ${ }^{11}$ resulting in aa mutation E321G was also found for BTV11 kc

Abbreviations: nd, genome segments of $\mathrm{p} 6$ and $\mathrm{p} 3 \mathrm{r}+\mathrm{p} 6$ without mutations in previous variants were not sequenced; -, no mutations 
heads indicated infection, replication and dissemination of wtBTV11. Bodies and heads in all three groups clearly segregated in PCR-positives and negatives. The percentage of PCR positives at $10 \mathrm{dpf}$ was similar for bodies and heads in each group, and was approximately $40 \%, 79 \%$ and $89 \%$ for group $\mathrm{L}, \mathrm{M}$ and $\mathrm{H}$, respectively (Fig. 5). The mean Cq value at $10 \mathrm{dpf}$ for each group mainly differed by the difference in percentage of infected midges, since the maximal $\mathrm{Cq}$ value for individual bodies was \pm 20 and for heads 22-23. Obviously, the difference in mean $\mathrm{Cq}$ values between 0 and $10 \mathrm{dpf}$ is less evident for bodies than for heads, in particular for group $\mathrm{H}$. Taken together, infection, replication and dissemination of wtBTV11 by blood-feeding of competent midges is demonstrated. As expected, the efficiency of infection of midges is dose-dependent. The 50\% infective virus titer - one 50\% Midge Alimentary Infective Dose $\left(\mathrm{MAID}_{50}\right)$ - is roughly calculated to a blood meal titer of $\pm 2 \times 10^{5} \mathrm{TCID}_{50} / \mathrm{ml}$ for wtBTV11. Thus, one MAID $_{50}$ corresponds to $\pm 20 \mathrm{TCID}_{50}$ wtBTV11 in a blood meal estimated to be $100 \mathrm{nl}$ for fully engorged competent $C$. sonorensis midges.
Differential virus replication in midges by deletion of 72 amino acid (aa) codons in Seg-10

BTV1 deficient for NS3/NS3a expression, named Disabled Infectious Single Animal (DISA) vaccine does not propagate in midges after intrathoracic inoculation [9]. Here, we studied virus propagation in detail after bloodfeeding of BTV11(S10 $\left.{ }^{\text {del }}\right)$ lacking a region in NS3/NS3a encompassing Late Domain, and is called 'DISA' Midges were blood-fed containing $\pm 2 \times 10^{6} \mathrm{TCID}_{50} / \mathrm{ml} \mathrm{DISA}$ or rgBTV11. This corresponded to $\pm 200 \mathrm{TCID}_{50}$ which is $\pm 10 \mathrm{MAID}_{50}$, and thus sufficient to infect a high percentage of midges. In addition, virus replication was studied after intrathoracic inoculation with the same amount of DISA vaccine virus.

Virus uptake by feeding or inoculation was confirmed by $100 \%$ PCR positive bodies at $0 \mathrm{dpf}$ and $0 \mathrm{dpi}$ (Fig. 6). Mean $\mathrm{Cq}$ values varied between groups, despite a normalized virus titer of rgBTV11 and DISA. As expected, the majority of heads (8 out of 10 fed midges) were PCRnegative at $0 \mathrm{dpf}$, whereas inoculation resulted in $100 \%$ PCR-positive heads. This suggests that inoculated virus rapidly disperses via the haemolymph into the head.

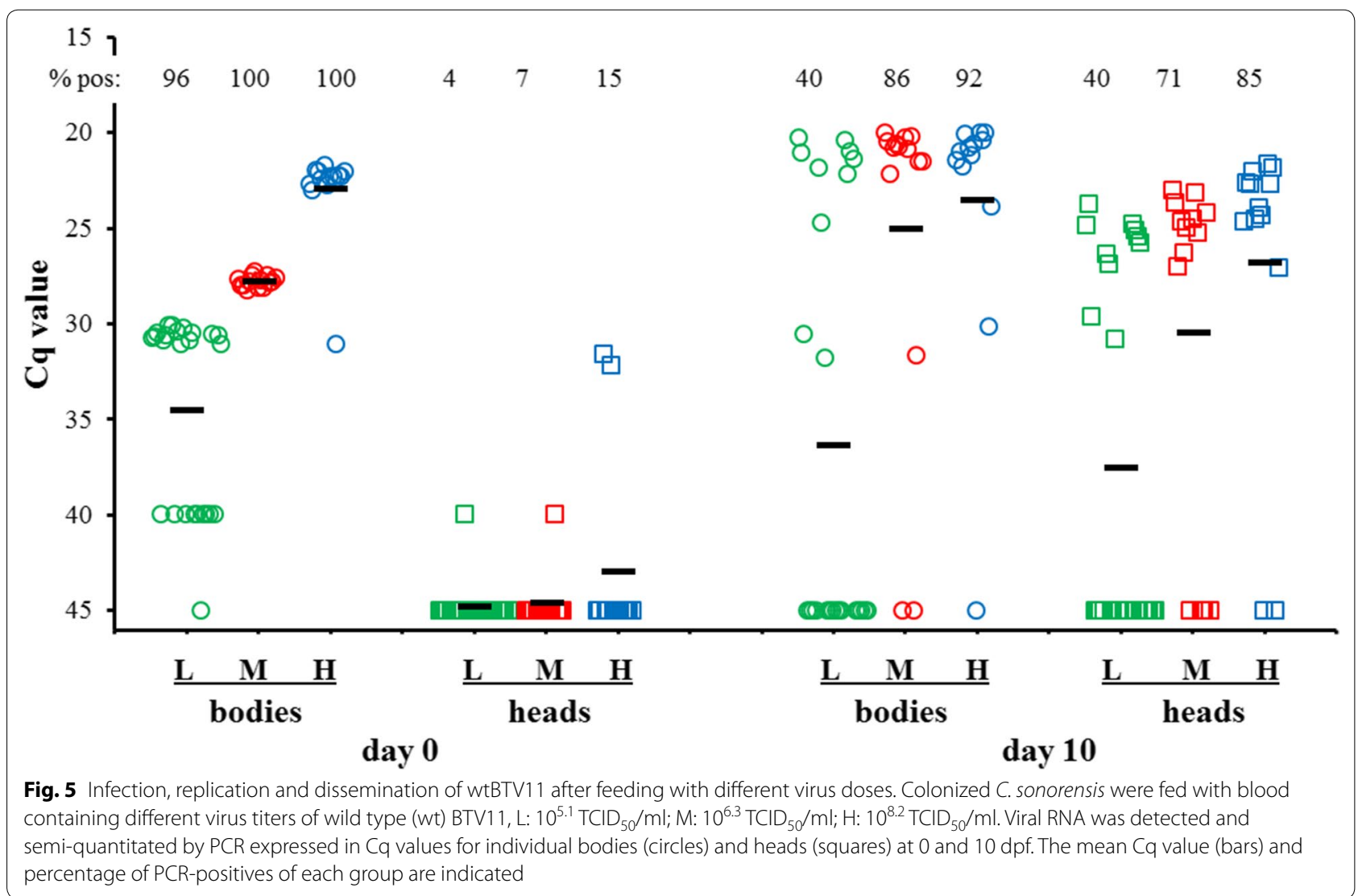


At $10 \mathrm{dpf}, 65 \%$ of the bodies and $44 \%$ of the heads of midges fed with rgBTV11 were PCR-positive, indicating infection, replication and dissemination of rgBTV11 (Fig. 6). However, the percentage of infected midges was lower than expected based on the calculated high dose of $10 \mathrm{MAID}_{50}$. Despite of 75\% PCR-positive bodies at 10 dpf with DISA, all heads remained PCR negative. Likely, DISA initially infected gut cells but is not released into the haemolymph and was therefore not disseminated to the head. DISA-propagation in competent midges after oral uptake was unsuccessful by lack of Late Domain in NS3/NS3a protein. After intrathoracic inoculation, a small decrease in mean $\mathrm{Cq}$ value (more virus) in bodies and heads was observed at $10 \mathrm{dpi}$. This indicated infection and replication of DISA after intrathoracic inoculation similarly as observed in bodies after blood-feeding. Deletion of Late Domain of NS3/NS3a protein caused differential virus propagation in vivo. We conclude that functional NS3/NS3a is essential for BTV propagation in competent midges after oral uptake. These results confirmed the DISA principle of BTV lacking functional NS3/NS3a expression.

\section{Differential virus replication in midges by point mutations} BTV11 $\left(\mathrm{S1}^{26}\right) \mathrm{bsr}$, BTV11 $\left(\mathrm{S1}^{26}\right) \mathrm{kc}$, and rgBTV11 were fed to midges using a normalized virus titer of $\pm 2 \times 10^{6}$ $\mathrm{TCID}_{50} / \mathrm{ml}$ (Fig. 7). Virus uptake was confirmed by
PCR-positivity for bodies at $0 \mathrm{dpf}$ for all three groups, except for two fed with BTV11(S1 $\left.{ }^{26}\right)$ bsr. As expected, rgBTV11 efficiently propagated in blood-fed midges, since bodies and heads at $10 \mathrm{dpf}$ were $80 \%$ and $88 \%$ PCRpositive, respectively (Fig. 7). Similarly, BTV11(S1 ${ }^{26}$ ) kc propagated in midges, as indicated by $>90 \%$ infected midges at $10 \mathrm{dpf}$. In contrast, BTV11 $\left(\mathrm{S}^{26}\right) \mathrm{bsr}$ showed $36 \%$ and 16\% PCR-positive bodies and heads at $10 \mathrm{dpf}$, respectively. This indicated that infection of midges by mammalian cell-adapted BTV11 $\left(\mathrm{S1}^{26}\right) \mathrm{bsr}$ was less efficient than by Culicoides-adapted BTV11 $\left(\mathrm{S}^{26}\right) \mathrm{kc}$ and rgBTV11. In addition, mean $\mathrm{Cq}$ values were higher (less virus) for BTV11 $\left(\mathrm{S1}^{26}\right) \mathrm{bsr}$ than for BTV11 $\left(\mathrm{S1}^{26}\right) \mathrm{kc}$ and rgBTV11 (Fig. 7). Apparently, BTV11(S1 $\left.{ }^{26}\right) \mathrm{kc}$ propagated similar to, or even slightly better than, rgBTV11 and more importantly, much better than BTV11(S1 $\left.{ }^{26}\right)$ bsr. We conclude that infection, replication and dissemination of BTV11 $\left(\mathrm{S}^{26}\right) \mathrm{kc}$ is more efficient in competent midges than of BTV11 $\left(\mathrm{S1}^{26}\right) \mathrm{bsr}$. Furthermore, the increased propagation in vitro and in vitro of BTV11 $\left(\mathrm{S}^{26}\right) \mathrm{kc}$ is likely caused by one aa mutation in outer shell protein VP2.

\section{Discussion}

Spread of arthropod-borne viruses depends on virus replication in the host and the competent insect vector leading to viremia in the host and virus excretion in

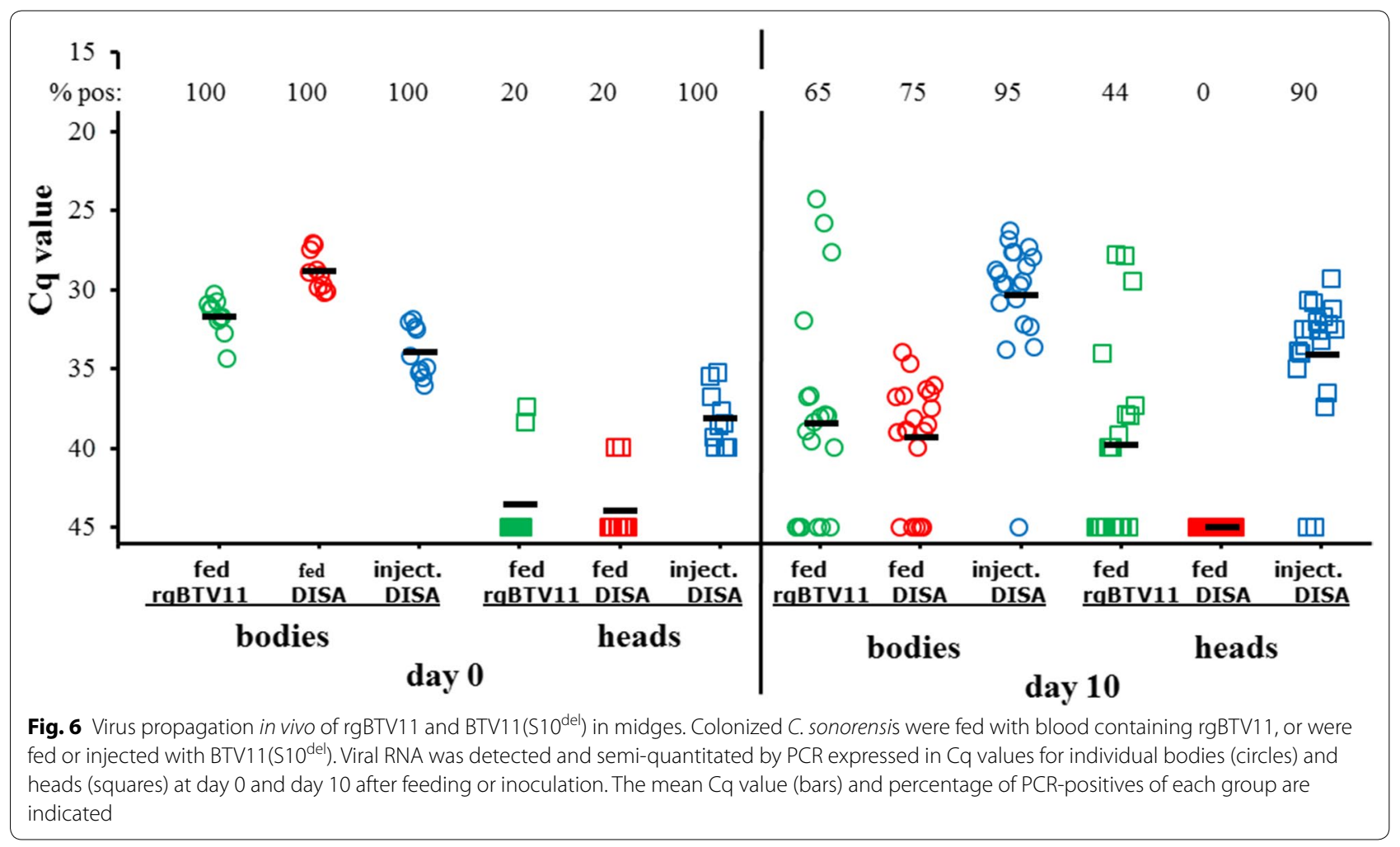




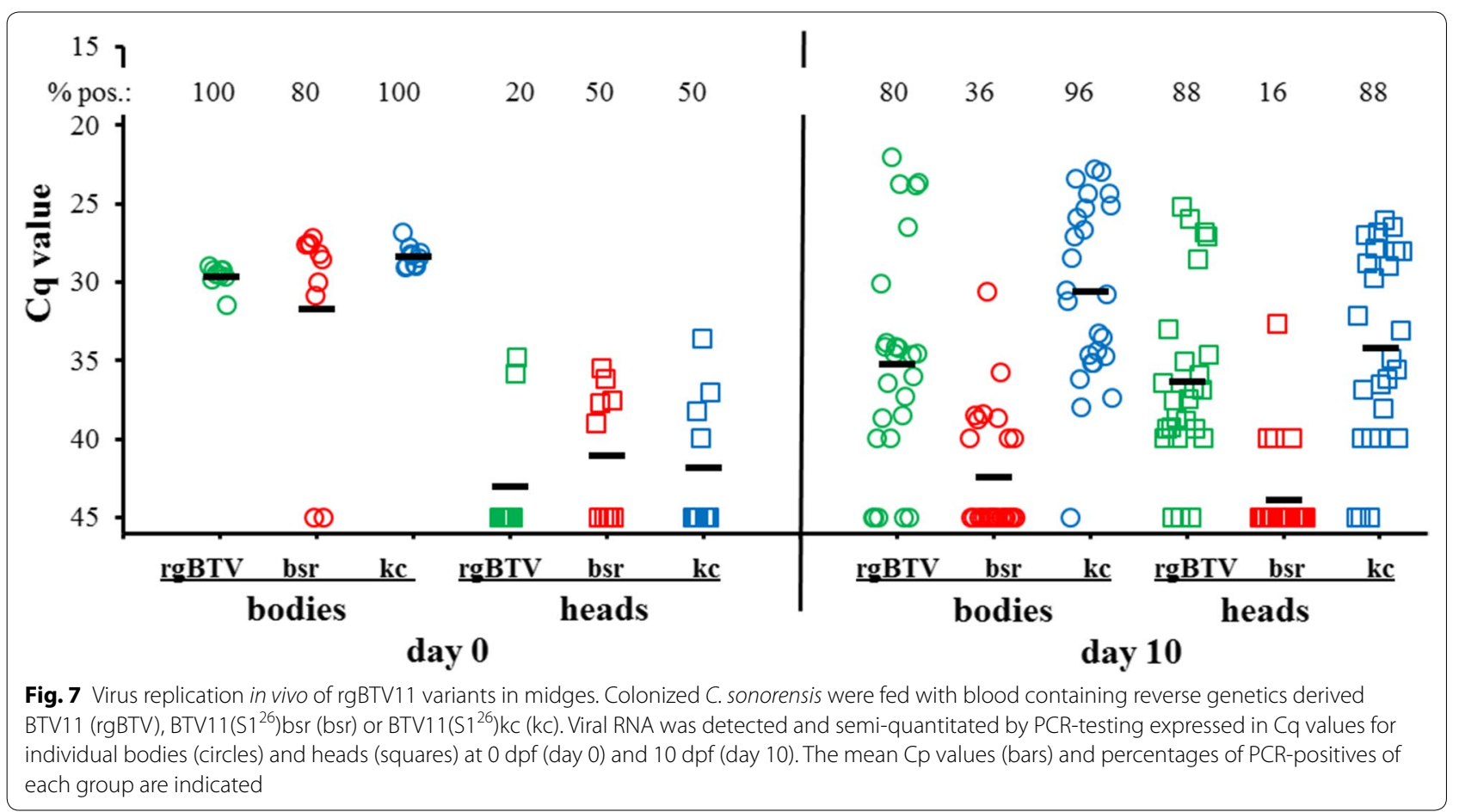

insect saliva, respectively. wtBTV11 infects competent C. sonorensis midges after oral uptake and can reach the midge head as early as on $3 \mathrm{dpf}$ and definitely on $7 \mathrm{dpf}$ [9]. In this previous study, a very high virus titer of $10^{8.2}$ $\mathrm{TCID}_{50} / \mathrm{ml}$ wtBTV11 served as control for virus propagation after blood-feeding as indicator for vector competence of midges [9]. A clear segregation of infected and non-infected bodies and heads at $10 \mathrm{dpf}$ further demonstrated the efficiency of infection, replication and dissemination of virus after blood-feeding. In the present study, we determined that $\pm 20 \mathrm{TCID}_{50}$ of wtBTV11-infected $50 \%$ of fully engorged midges (Fig. 5), which is named one $50 \%$ Midge Alimentary Infective Dose or $\mathrm{MAID}_{50}$. One MAID $_{50}$ of wtBTV11 corresponds to a complete blood meal of $100 \mathrm{nl}$ containing $\pm 2 \times 10^{5} \mathrm{TCID}_{50} / \mathrm{ml}$ wtBTV11. Previously, a virus titer of $10^{5.8} \mathrm{TCID}_{50} / \mathrm{ml}\left( \pm 6 \times 10^{5}\right.$ $\left.\mathrm{TCID}_{50}\right)$ of reverse genetics derived BTV1 reassortant (corresponding to $\pm 3 \mathrm{MAID}_{50}$ of wtBTV11) did not infect competent midges, although intrathoracic inoculation was successful [9]. Clearly, infection of midges by blood-feeding depends on the MAID ${ }_{50}$ but likely the used virus strain is even more important. The midge feeding model was used to study propagation of BTV11 mutants in more detail.

BTV11 was rescued by reverse genetics aiming to identify viral genes involved in vector competence. Expectedly, 'synthetic' BTV11 (rgBTV11) replicated well in BSR and $\mathrm{KC}$ cells (Fig. 1), and infected $C$. sonorensis midges after blood-feeding (Figs. 6 and 7). However, mean Cq values were higher (less rgBTV11) than for wtBTV11, but PCR results for bodies and heads at $10 \mathrm{dpf}$ varied more for rgBTV11-infected midges (Fig. 5 versus Figs. 6 and 7). This variation suggests that infection, replication or dissemination of rgBTV11 is slightly slower than of wtBTV11. However, the percentage of infected midges differed between feeding experiments with rgBTV11 suggesting some variation in competence between hatches/ batches of midges (Figs. 6 and 7). Nonetheless, rgBTV11infected midges after oral uptake, was released into the haemolymph, and was disseminated to the head. Thus, rgBTV11 is a suitable virus backbone to test BTV11 mutants in the midge feeding model.

NS3/NS3a protein is the prototype BTV gene involved in differentiating virus replication in cell lines of the mammalian host and the midge vector $[10,11,35]$. NS3/NS3a knockout mutants have been developed as DISA vaccines [36]), and show 'differential virus replication' in vivo [9]. BTV11(S10 $\left.{ }^{\mathrm{del}}\right)$ (here named DISA) lacking Late Domain of NS3/NS3a demonstrates similar characteristics (Figs. 1, 6). Here, we also showed that blood-feeding with a high titer of DISA vaccine virus infected midguts and weakly replicated but was not disseminated to the head (Fig. 6). In conclusion, DISA vaccine virus with a small deletion of 72 aa codons in NS3/ NS3a protein cannot reach salivary glands and will not be excreted by midges to susceptible hosts during bloodfeeding. The deletion in BTV11 $\left(\mathrm{S} 10^{\mathrm{del}}\right)$ corresponds to the in-frame deletion of 77 aa codons in the experimental 
DISA vaccine for African Horse Sickness [36, 37]. Similar to the BTV DISA vaccine, this NS3/NS3a mutant of African horse sickness virus (AHSV) is not virulent, and showed similar in vitro characteristics. It is likely that it would also be blocked in virus release and dissemination in blood-fed midges. Taken together, a small deletion in NS3/NS3a protein encompassing Late Domain is sufficient to establish nonvirulence, the DIVA principle (Differentiating Infected from Vaccinated), and the DISA principle (Disabled Infectious Single Animal) (reviewed in [38]).

Pullinger et al. [20] have shown differential virus replication in vitro for several reassortants of typical BTV1 and atypical BTV26. In this study, we aimed to determine differential virus replication in vivo, and rescued typical BTV11 with $\mathrm{S}^{26}$. Rescue of BTV11 $\left(\mathrm{S}^{26}\right)$ was less efficient than BTV11, and adaptive changes after rescue were assumed to improve virus growth on BSR cells. In agreement with Pullinger et al. [20], BTV11 $\left(\mathrm{S1}^{26}\right)$ initially showed limited virus production in $\mathrm{KC}$ cells (Fig. 3). Interestingly, we were able to adapt BTV11( $\left(\mathrm{S}^{26}\right)$ to KC cells. BTV11 $\left(\mathrm{S1}^{26}\right) \mathrm{kc}$ had obvious phenotypical differences as observed by increased virus growth and enlargement of immunostained foci in infected $\mathrm{KC}$ cell monolayers (Figs. 2, 4). Additionally, replication of virus passaged rgBTV11kc was slightly increased in $\mathrm{KC}$ cells and immunostained foci in $\mathrm{KC}$ cell monolayers were also slightly larger compared to virus passaged BTV11bsr. These results indicated adaptation for virus growth in $\mathrm{KC}$ cells for both BTV11 $\left(\mathrm{S1}^{26}\right) \mathrm{kc}$ and rgBTV11kc. BTV11 $\left(\mathrm{S1}^{26}\right)$ was independently rescued again, and in addition, an $\mathrm{S}^{26}$ mono-reassortant of BTV1 strain RSArrrr/01 was rescued (BTV1 $\left(\mathrm{S1}^{26}\right)$ according to previous results [20]. As expected, both $\mathrm{S}^{26}$ mono-reassortants showed hardly replication in $\mathrm{KC}$ cells but could be adapted to $\mathrm{KC}$ cells (Fig. 2). We conclude that differential virus replication of $\mathrm{S}^{26}$ mono-reassortant of BTV1 and BTV11 was abolished by virus passages in KC cells suggesting adaptation mutations in one or more genome segments.

Adaptation mutations were identified but, more importantly, corrections of chimeric interactions and adaptation mutations could be distinguished (Table 1). BTV11kc contained one aa mutation in VP2 protein, whereas BTV11bsr did not contain mutations. Similarly, rescued virulent BTV8 and nonvirulent BTV6 did not change after rescue in BSR cells [25]. Of note, passaged BTV11kc and BTV11 bsr were partially sequenced and mutations outside the regions of interest cannot be ruled out (Table 1). Viruses exhibit adaptation mutations known as genetic drifting, but arise of adaptive changes strongly depends on the selection pressure in the field or during in vitro virus passages [39-42]).
Five nucleotide mutations were found in rescued $\mathrm{BTV}\left(\mathrm{S}^{26}\right)$ (Table 1). Four mutations implicated aa mutations in VP1 ${ }^{26}, \mathrm{VP}^{11}$ and two in NS2 ${ }^{11}$. The aa mutations were rapidly selected after virus rescue assuming interactions with exchanged VP1 ${ }^{26}$ and suggested a strong selection. Likely, these improve chimeric interactions between VP1 ${ }^{26}$ and BTV11 proteins since these were not found in BTV11. In addition, no aa mutations were found in $\mathrm{S}^{26}$ after passages of BTV26 on BSR cells. VP1, VP4, and NS2 are all associated with the replication machinery. Amino acid mutation D309G in $\mathrm{VP1}{ }^{26}$ is not unique and seems to be associated with eastern topotypes of BTV. BTV1 $\left(\mathrm{S}^{26}\right)$ contained the same point mutation leading to the D309G aa mutation, while independently rescued $\mathrm{BTV} 11\left(\mathrm{~S}^{26}\right)$ had a point mutation G936A leading to aa mutation D309N. These results demonstrate the importance of mutating Asp on aa position 309. Asp-309 is mapped in the unmodelled region between NTD and PD of RdRp and has been suggested to interact with virus proteins of the replication complex [29]. We propose that D309G or D309N improves chimeric protein interactions of VP $1{ }^{26}$ with proteins of BTV1 or BTV11 resulting in increased virus replication in both BSR and KC cells (Fig. 4).

The aa mutation L399S in VP4 ${ }^{11}$ of $\mathrm{BTV} 11\left(\mathrm{~S}^{26}\right)$ is a non-conserved aa residue. The VP4, a capping enzyme, is part of the replication complex and catalyses the formation of a cap1 structure at the 5' termini of core RNA transcripts. VP4 has distinct domains for its different activities [43]. The aa mutation L399S is located in the second region of the N7MTase domain (residues $110-170$ and $380-500)$ suggesting a role in this activity. However, it is more likely that the L399S aa mutation improves chimeric interactions between VP4 and VP1 than capping activities of VP4, since assembly of the replication complex starts with interactions between VP1 and VP4.

$\mathrm{NS} 2^{11}$ of rescued BTV11(S126) contained aa mutations L171F and E221G. NS2 of atypical BTV25-27 also contained F-171, and E-221 in NS2 of atypical BTVs is highly conserved within a variable region. Independently rescued $\mathrm{BTV} 11\left(\mathrm{~S}^{26}\right)$ also contained L171F but E221G was not found, whereas $\mathrm{S}^{1}$ of rescued BTV1 $\left(\mathrm{S}^{26}\right)$ was not mutated. We speculate that these aa residues of NS2 are involved in interactions with VP1. NS2 recruits viral ssRNA from the cytoplasm, but its interactions with core proteins VP1, 3, 4, 6, and 7 are largely unknown (reviewed in [44]). Our results support the biological evidence that NS2 is associated to VP1.

One aa mutation in $\mathrm{VP}^{26}$, one aa mutation in $\mathrm{VP}^{11}$, and one silent mutation in $\mathrm{S}^{26}$ were found in BTV11 $\left(\mathrm{S}^{26}\right) \mathrm{kc}$ (Table 1). These mutations were either still mixed, like the silent mutation on nucleotide position 
2393 in $\mathrm{S} 2^{11}$, or arose very late after several virus passages. We assume that selection for these mutations was very weak or absent and consider these as natural variations after rescue of (clonal) virus. More importantly, no obvious mutations in $\mathrm{VP}^{26}$ were found that are associated to adaptation to virus growth in KC cells. Surprisingly, we found that $\mathrm{VP} 1^{26}$ is not involved in differential virus replication in vitro.

The most obvious difference between BTV11 $\left(\mathrm{S}^{26}\right)$ $\mathrm{kc}$ and BTV11 $\left(\mathrm{S}^{26}\right) \mathrm{bsr}$ is nucleotide mutation A981G in $\mathrm{S}^{11}$ resulting in $\mathrm{E} 321 \mathrm{G}$ in $\mathrm{VP} 2^{11}$ (Table 1). BTV11kc contained the same aa mutation and is the only difference compared to BTV11bsr. Apparently, aa mutation E321G in VP2 favoured virus replication in vitro (Fig. 4). Independently rescued BTV11 $\left(\mathrm{S}^{26}\right)$ contained also mutations in VP2 ${ }^{11}$; E401G and $\mathrm{I} 503 \mathrm{~V}$, and the $\mathrm{S}^{26}$ chimeric virus based on BTV serotype 1 also contained one N229S mutation in $\mathrm{VP}^{1}$. In a previous study, BTV8/net07/e1 was also passaged in KC cells (BTV8/net07/e1kc3) leading to two nucleotide changes of which one resulted in $\mathrm{R} 400 \mathrm{G}$ in $\mathrm{VP} 2^{8}$ [25]. VP2 reportedly binds to the cell surface receptor and to a cell surface glycoprotein by its sialic acid binding domain in the central hub domain of VP2 [45]. We noticed that adaptive mutations in $\mathrm{VP}^{11}$ are located in or close to the externally exposed flexible tip domain of VP2 mapped to aa 191-407. A similar region of VP2 (aa residues 278-504) has been shown for AHSV [46]. This region in AHSV-VP2 is not essential for in vitro virus replication in both cell types, but the corresponding region (aa residues 284-510) in AHSV4-VP2 seems to be involved specifically in virus replication in $\mathrm{KC}$ cells, since virus release from $\mathrm{KC}$ cells of this AHSV deletion mutant was slightly delayed [47]. Altogether, mutations in VP2 of these midge-borne orbiviruses are strongly associated with adaptation to $\mathrm{KC}$ cells confirming that VP2 is involved in differential virus replication in vitro.

In order to identify proteins or domains involved in differential virus replication in vivo and thus important for vector competence, RdRp VP1 was a promising candidate [20]. However, no domain in VP1 involved in differential virus replication was identified. Instead, VP2 was found to be a key candidate affecting vector competence. Indeed, outer shell proteins VP2 and VP5 of atypical BTV26 also blocked virus replication in KC cells [20]. Differential virus replication in vitro caused by one aa mutation in VP2 was found in rgBTV11 but was more pronounced in combination with VP1 of atypical BTV26 (Fig. 4). More importantly, BTV11 $\left(\mathrm{S1}^{26}\right) \mathrm{kc}$ propagated better in competent midges than BTV11(S1 $\left.{ }^{26}\right)$ bsr (Fig. 7). It is very tempting to speculate that aa mutation E321G in $\mathrm{VP}^{11}$ solely caused this differential virus replication in vivo. Indeed, partial sequencing of viral RNA isolated from fed midges at $10 \mathrm{dpf}$ confirmed previous mutations, indicating no reversion or selection of certain mutations after oral uptake. More research on VP2 is needed on independently rescued and adapted virus variants to study the role of VP2 in vector competence.

BTV8 re-emerged in France in 2015 and reportedly spreads much slower than the BTV8 strain causing the huge epidemic in north-western Europe in 2006-2009. These BTV8 strains are closely related and contain 11 aa differences scattered over seven genome segments/ proteins, including three in VP1 and one in VP2 [48]. The re-emerging BTV8 strain is less virulent, causing a lower viremia, and showing a reduced vector competence [48]. The latter might be caused by the lower viremia in the host, and reduced virus propagation in midges after standardized blood-feeding cannot be excluded. Reverse genetics for BTV8 and the midge feeding model presented here with separate testing of bodies and heads, could be used to elucidate the role of each of these aa mutations in virus propagation in midges.

\section{Conclusions}

The midge feeding model, including decapitation and separate testing of individual bodies and heads, is a suitable approach to identify viral factors involved in propagation of virus mutants in more detail. One MAID $_{50}(50 \%$ Midge Alimentary Infective Dose) of wtBTV11 infects 50\% of fully engorged midges and corresponds to a complete blood meal of $100 \mathrm{nl}$ containing $\pm 2 \times 10^{5} \mathrm{TCID}_{50} / \mathrm{ml}$ or 20 TCID $_{50}$ wtBTV11. Clearly, infection of midges by bloodfeeding depends on virus uptake but the used virus strain is even more important. A small 72 amino acid in-frame deletion of NS3/NS3a protein completely blocks virus dissemination in blood-fed midges. Further, detailed knowledge of protein-protein interactions in the virion was generated by analysis of BTV reassortants. In addition, a point mutation in outer shell protein VP2 was identified in Culicoides-adapted BTV that is associated with differential virus replication in vitro and in vivo and thus with vector competence. In conclusion, two examples of small changes in BTV are shown which strongly affect virus infection, replication and dissemination of virus in competent midges. All these processes are part of the key mechanism crucial for vector competence and thus for spread of the bluetongue virus.

\section{Abbreviations}

BT: Bluetongue; BTV: bluetongue virus; CPE: cytopathogenic effect; Cq: quantification cycle; CTD: C-terminal domain; DMEM: Dulbecco's modified Eagle's medium; dpf: days post-feeding; dpi: days post-inoculation; FBS: foetal bovine serum; hpi: hours post-infection; IPMA: immunoperoxidase monolayer assay; MAID: midge alimentary infective dose; MOI: multiplicity of infection; NTD:

$\mathrm{N}$-terminal domain; PCR: polymerase chain reaction; PBS: phosphate-buffered saline; PD: polymerase domain; RdRp: RNA-dependent RNA polymerase; rg: reverse genetics; TCID: tissue cell infective dose; WBVR: Wageningen Bioveterinary Research; wt: wild type. 


\section{Acknowledgements}

We thank Dr. Dustin Swanson and Mr. William Yarnell at the Arthropod-Borne Animal Diseases Research Unit, USDA, ARS, Manhattan, KS, USA, for providing C. sonorensis midges.

\section{Authors' contributions}

RGPVG designed and carried out in vitro experiments, and wrote the first draft. BSD helped designing midge experiments, carried out midge experiments, interpreted the data, and corrected the manuscript. PRL carried out midge experiments. JB processed midges, carried out RNA isolations and RT PCR assays, and AJCR performed experiments with chimeric Seg-1[VP1]. PAvR headed the project, designed the experiments, interpreted the data and finalized the manuscript. All authors read and approved the final manuscript.

\section{Funding}

This research was financially supported by project WOT-01-003-079 and KB-21-006-030 of the Dutch Ministry of Agriculture, Nature and Food Quality (LNV)(WBVR-project no. 1600001423), and USDA, ARS, NP103 Animal Health National Programme, project no. 3020-32000-010.

\section{Availability of data and materials}

Data supporting the conclusions of this article are included within the article. The datasets used and/or analysed during the present study are available from the corresponding author upon reasonable request.

\section{Ethics approval and consent to participate}

Not applicable.

\section{Consent for publication}

Not applicable.

\section{Competing interests}

The authors declare that they have no competing interests.

\section{Author details}

${ }^{1}$ Department of Virology, Wageningen Bioveterinary Research, Lelystad, The Netherlands. ${ }^{2}$ Arthropod-Borne Animal Diseases Research Unit, Centre for Grain and Animal Health Research, USDA-ARS, Manhattan, KS, USA. ${ }^{3}$ Kansas State University, Manhattan, KS, USA. ${ }^{4}$ Department of Biochemistry, Centre for Human Metabolomics, North-West University, Potchefstroom, South Africa.

Received: 20 June 2019 Accepted: 16 September 2019

Published online: 11 October 2019

\section{References}

1. Gubler DJ. The global emergence/resurgence of arboviral diseases as public health problems. Arch Med Res. 2002;33:330-42.

2. Weaver SC, Reisen WK. Present and future arboviral threats. Antiviral Res. 2010;85:328-45

3. Maan S, Maan NS, Samuel AR, Rao S, Attoui H, Mertens PP. Analysis and phylogenetic comparisons of full-length VP2 genes of the 24 bluetongue virus serotypes. J Gen Virol. 2007;88:621-30.

4. Savini G, Lorusso A, Paladini C, Migliaccio P, Di Gennaro A, Di Provvido $A$, et al. Bluetongue serotype 2 and 9 modified live vaccine viruses as causative agents of abortion in livestock: a retrospective analysis in Italy. Transbound Emerg Dis. 2014;61:69-74.

5. Gibbs EP, Lawman MJ, Herniman KA. Preliminary observations on transplacental infection of bluetongue virus in sheep-a possible overwintering mechanism. Res Vet Sci. 1979;27:118-20.

6. Menzies FD, McCullough SJ, McKeown IM, Forster JL, Jess S, Batten C, et al. Evidence for transplacental and contact transmission of bluetongue virus in cattle. Vet Rec. 2008;163:203-9.

7. Backx A, Heutink R, van Rooij E, van Rijn P. Transplacental and oral transmission of wild-type bluetongue virus serotype 8 in cattle after experimental infection. Vet Microbiol. 2009;138:235-43.

8. Santman-Berends IM, van Wuijckhuise L, Vellema P, van Rijn PA. Vertical transmission of bluetongue virus serotype 8 virus in Dutch dairy herds in 2007. Vet Microbiol. 2010;141:31-5.
9. Feenstra F, Drolet BS, Boonstra J, van Rijn PA. Non-structural protein NS3/ NS3a is required for propagation of bluetongue virus in Culicoides sonorensis. Parasit Vectors. 2015:8:476.

10. Feenstra F, van Gennip RG, Maris-Veldhuis M, Verheij E, van Rijn PA. Bluetongue virus without NS3/NS3a expression is not virulent and protects against virulent bluetongue virus challenge. J Gen Virol. 2014;95:2019-29.

11. van Gennip RG, van de Water SG, van Rijn PA. Bluetongue virus nonstructural protein NS3/NS3a is not essential for virus replication. PLoS One. 2014:9:e85788.

12. Hofmann MA, Renzullo S, Mader M, Chaignat V, Worwa G, Thuer B. Genetic characterization of toggenburg orbivirus, a new bluetongue virus, from goats, Switzerland. Emerg Infect Dis. 2008;14:1855-61.

13. Maan S, Maan NS, Ross-smith N, Batten CA, Shaw AE, Anthony SJ, et al. Sequence analysis of bluetongue virus serotype 8 from the Netherlands 2006 and comparison to other European strains. Virology. 2008;377(2):308-18.

14. Zientara S, Sailleau C, Viarouge C, Hoper D, Beer M, Jenckel M, et al. Novel bluetongue virus in goats, Corsica, France, 2014. Emerg Infect Dis. 2014;20(12):2123-32.

15. Marcacci M, Sant S, Mangone I, Goria M, Dondo A, Zoppi S, et al. One after the other: a novel bluetongue virus strain related to Toggenburg virus detected in the Piedmont region (north-western Italy), extends the panel of novel atypical BTV strains. Transbound Emerg Dis. 2018;65:370-4.

16. Chaignat V, Worwa G, Scherrer N, Hilbe M, Ehrensperger F, Batten C, et al. Toggenburg Orbivirus, a new bluetongue virus: initial detection, first observations in field and experimental infection of goats and sheep. Vet Microbiol. 2009:138:11-9.

17. Batten C, Darpel K, Henstock M, Fay P, Veronesi E, Gubbins S, et al. Evidence for transmission of bluetongue virus serotype 26 through direct contact. PLoS One. 2014;9:e96049.

18. Breard E, Schulz C, Sailleau C, Bernelin-Cottet C, Viarouge C, Vitour D, et al Bluetongue virus serotype 27: experimental infection of goats, sheep and cattle with three BTV-27 variants reveal atypical characteristics and likely direct contact transmission BTV-27 between goats. Transbound Emerg Dis. 2018;65:e251-63.

19. van Rijn PA, van de Water SG, Maris-Veldhuis MA, van Gennip RG. Experimental infection of small ruminants with bluetongue virus expressing Toggenburg Orbivirus proteins. Vet Microbiol. 2016;192:145-51.

20. Pullinger GD, Guimera Busquets M, Nomikou K, Boyce M, Attoui H, Mertens PP. Identification of the genome segments of bluetongue virus serotype 26 (Isolate KUW2010/02) that restrict replication in a Culicoides sonorensis cell Line (KC Cells). PLoS One. 2016:11:e0149709.

21. Sato M, Tanaka H, Yamada T, Yamamoto N. Persistent infection of BHK21/ WI-2 cells with rubella virus and characterization of rubella variants. Arch Virol. 1977;54:333-43.

22. Wechsler SJ, McHolland LE, Tabachnick WJ. Cell lines from Culicoides variipennis (Diptera: Ceratopogonidae) support replication of bluetongue virus. J Invertebr Pathol. 1989;54:385-93.

23. Maan S, Maan NS, Nomikou K, Veronesi E, Bachanek-Bankowska K, Belaganahalli MN, et al. Complete genome characterisation of a novel 26th bluetongue virus serotype from Kuwait. PLoS One. 2011;6:e26147.

24. van Rijn PA, van de Water SG, Feenstra F, van Gennip RG. Requirements and comparative analysis of reverse genetics for bluetongue virus (BTV) and African horse sickness virus (AHSV). Virol J. 2016;13:119.

25. van Gennip RG, van de Water SG, Potgieter CA, Wright IM, Veldman D, van Rijn PA. Rescue of recent virulent and avirulent field strains of bluetongue virus by reverse genetics. PLoS One. 2012;7:e30540.

26. Boyce M, Celma CC, Roy P. Development of reverse genetics systems for bluetongue virus: recovery of infectious virus from synthetic RNA transcripts. J Virol. 2008:82:8339-48.

27. Gaudreault NN, Jasperson DC, Dubovi EJ, Johnson DJ, Ostlund EN, Wilson WC. Whole genome sequence analysis of circulating bluetongue virus serotype 11 strains from the United States including two domestic canine isolates. J Vet Diagn Invest. 2015;27:442-8.

28. Wirblich C, Bhattacharya B, Roy P. Nonstructural protein 3 of bluetongue virus assists virus release by recruiting ESCRT-I protein Tsg101. J Virol. 2006;80:460-73.

29. Wehrfritz JM, Boyce M, Mirza S, Roy P. Reconstitution of bluetongue virus polymerase activity from isolated domains based on a three-dimensional structural model. Biopolymers. 2007;86:83-94. 
30. Potgieter AC, Page NA, Liebenberg J, Wright IM, Landt O, van Dijk AA. Improved strategies for sequence-independent amplification and sequencing of viral double-stranded RNA genomes. J Gen Virol. 2009;90:1423-32.

31. Jones RH, Foster NM. Oral infection of Culicoides variipennis with bluetongue virus: development of susceptible and resistant lines from a colony population. J Med Entomol. 1974;11:316-23.

32. Hunt GJ, McKinnon CN. Evaluation of membranes for feeding Culicoides variipennis (Diptera: Ceratopogonidae) with an improved artificial bloodfeeding apparatus. J Med Entomol. 1990;27:934-7.

33. Toussaint JF, Sailleau C, Breard E, Zientara S, De Clercq K. Bluetongue virus detection by two real-time RT-qPCRs targeting two different genomic segments. J Virol Methods. 2007;140:115-23.

34. van Rijn PA, Heutink RG, Boonstra J, Kramps HA, van Gennip RG. Sustained high-throughput polymerase chain reaction diagnostics during the European epidemic of bluetongue virus serotype 8. J Vet Diagn Invest 2012;24:469-78.

35. Feenstra F, van Gennip RG, van de Water SG, van Rijn PA. RNA elements in open reading frames of the bluetongue virus genome are essential for virus replication. PLoS One. 2014:9:e92377.

36. van Rijn PA, Maris-Veldhuis MA, Boonstra J, van Gennip HGP. Diagnostic DIVA tests accompanying the Disabled Infectious Single Animal (DISA) vaccine platform for African horse sickness. Vaccine. 2018;36:3584-92.

37. van Rijn PA, Maris-Veldhuis MA, Potgieter AC, van Gennip HGP. African horse sickness virus (AHSV) with a deletion of 77 amino acids in NS3/ NS3a protein is not virulent and a safe promising AHS Disabled Infectious Single Animal (DISA) vaccine platform. Vaccine. 2018;36:1923-33.

38. Feenstra F, van Rijn PA. Current and next-generation bluetongue vaccines: Requirements, strategies, and prospects for different field situations. Crit Rev Microbiol. 2017:43:142-55.

39. Brookes DW, Miah S, Lackenby A, Hartgroves L, Barclay WS. Pandemic H1N1 2009 influenza virus with the H275Y oseltamivir resistance neuraminidase mutation shows a small compromise in enzyme activity and viral fitness. J Antimicrob Chemother. 2011;66:466-70.
40. Dam E, Quercia R, Glass B, Descamps D, Launay O, Duval X, et al. Gag mutations strongly contribute to HIV-1 resistance to protease inhibitors in highly drug-experienced patients besides compensating for fitness loss. PLOS Pathog. 2009;5:e1000345.

41. Kortekaas J, Vloet RP, Weerdmeester K, Ketelaar J, van Eijk M, Loeffen WL. Rational design of a classical swine fever C-strain vaccine virus that enables the differentiation between infected and vaccinated animals. J Virol Methods. 2010;163:175-85.

42. Rimmelzwaan GF, Berkhoff EG, Nieuwkoop NJ, Smith DJ, Fouchier RA, Osterhaus AD. Full restoration of viral fitness by multiple compensatory co-mutations in the nucleoprotein of influenza A virus cytotoxic T-lymphocyte escape mutants. J Gen Virol. 2005;86:1801-5.

43. Roy P. Bluetongue virus structure and assembly. Curr Opin Virol. 2017;24:115-23.

44. Butan C, Tucker P. Insights into the role of the non-structural protein 2 (NS2) in bluetongue virus morphogenesis. Virus Res. 2010;151:109-17.

45. Zhang X, Patel A, Celma CC, Yu X, Roy P, Zhou ZH. Atomic model of a nonenveloped virus reveals $\mathrm{pH}$ sensors for a coordinated process of cell entry. Nat Struct Mol Biol. 2016;23:74-80.

46. Manole V, Laurinmaki P, Van Wyngaardt W, Potgieter CA, Wright IM, Venter GJ, et al. Structural insight into African horsesickness virus infection. J Virol. 2012;86:7858-66.

47. van Gennip RG, van de Water SG, Potgieter CA, van Rijn PA. Structural protein VP2 of African horse sickness virus is not essential for virus replication in vitro. J Virol. 2017:91:e01328-416.

48. Flannery J, Sanz-Bernardo B, Ashby M, Brown H, Carpenter S, Cooke L, et al. Evidence of reduced viremia, pathogenicity and vector competence in a re-emerging European strain of bluetongue virus serotype 8 in sheep. Transbound Emerg Dis. 2019;66:1177-85.

\section{Publisher's Note}

Springer Nature remains neutral with regard to jurisdictional claims in published maps and institutional affiliations.
Ready to submit your research? Choose BMC and benefit from:

- fast, convenient online submission

- thorough peer review by experienced researchers in your field

- rapid publication on acceptance

- support for research data, including large and complex data types

- gold Open Access which fosters wider collaboration and increased citations

- maximum visibility for your research: over $100 \mathrm{M}$ website views per year

At BMC, research is always in progress.

Learn more biomedcentral.com/submissions 